NBER WORKING PAPER SERIES

\title{
THE GERMAN PUBLIC PENSION SYSTEM: HOW IT WAS, HOW IT WILL BE
}

\author{
Axel Börsch-Supan \\ Christina B. Wilke \\ Working Paper 10525 \\ http://www.nber.org/papers/w10525
}

\section{NATIONAL BUREAU OF ECONOMIC RESEARCH 1050 Massachusetts Avenue Cambridge, MA 02138}

May 2004

This paper was commissioned by the Michigan Retirement Research Center (MRRC). Additional financial support was provided by the National Institute on Aging (NIA) through the NBER, the German Science Foundation (DFG) through the Sonderforschungsbereich 504, the State of Baden-Württemberg and the German Insurers Association (GDV). We are grateful for many helpful comments by Anette Reil-Held and the participants of the MRRC Conference on Improving Social Security Programs at the University of Maryland, September 13, 2003. The views expressed herein are those of the author(s) and not necessarily those of the National Bureau of Economic Research.

C2004 by Axel Börsch-Supan and Christina B. Wilke. All rights reserved. Short sections of text, not to exceed two paragraphs, may be quoted without explicit permission provided that full credit, including (C) notice, is given to the source. 
The German Public Pension System: How it Was, How it Will Be Axel Börsch-Supan and Christina B. Wilke

NBER Working Paper No. 10525

May 2004

JEL No. H0, H8

\title{
$\underline{\text { ABSTRACT }}$
}

Germany still has a very generous public pay-as-you-go pension system. It is characterized by early effective retirement ages and very high effective replacement rates. Most workers receive virtually all of their retirement income from this public retirement insurance. Costs are almost 12 percent of GDP, more than 2.5 times as much as the U.S. Social Security System. The pressures exerted by population aging on this monolithic system, amplified by negative incentive effects, have induced a reform process that began in 1992 and is still ongoing. This process is the topic of this paper. It has two parts. Part A describes the German pension system as it has shaped the labor market until about the year 2000. Part B describes the three staged reform process that will convert the exemplary and monolithic Bismarckian public insurance system after the year 2000 into a complex multipillar system. The paper delivers an assessment in how far these reform steps will solve the pressing problems of a prototypical pay-as-you-go system of old age provision, hopefully with lessons for other countries with similar problems.

\author{
Axel Börsch-Supan \\ Department of Economics \\ University of Mannheim \\ Building L13, 17 \\ D-68131 Mannheim \\ GERMANY \\ and NBER \\ axel@boersch-supan.de \\ Christina B. Wilke \\ Mannheim Research Institute for the Economics of Aging \\ Mannheim, Germany
}




\section{Content}

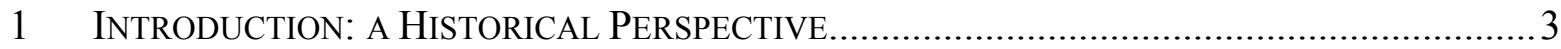

PART A: THE GERMAN PUBLIC PENSION SYSTEM HOW IT WAS .........................10

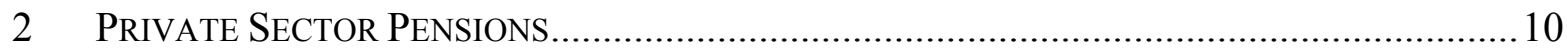

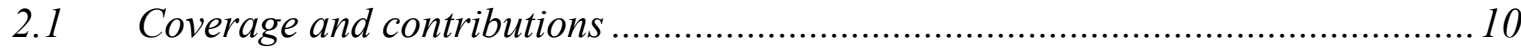

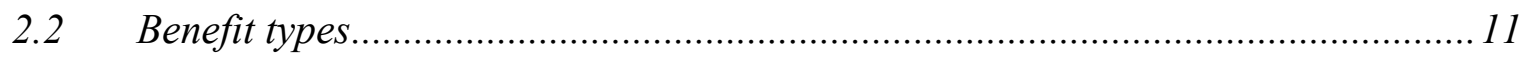

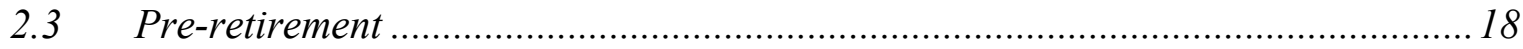

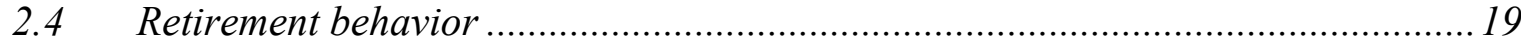

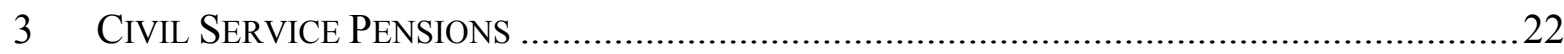

3.1 Eligibility: pathways to retirement for civil servants ............................................23

3.2 Computation of civil servants' pensions................................................................23

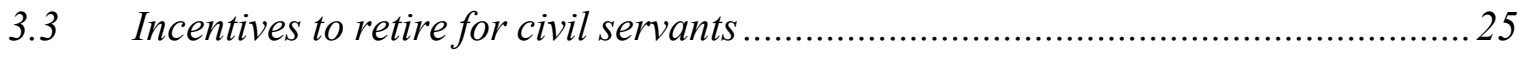

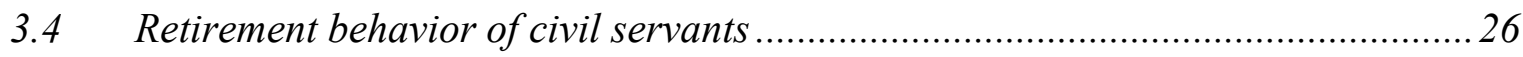

PART B: THE GERMAN PUBLIC PENSION SYSTEM HOW IT WILL BE...................27

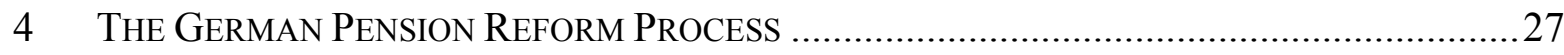

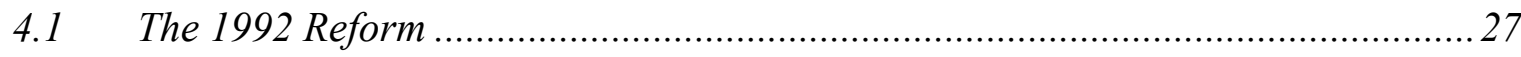

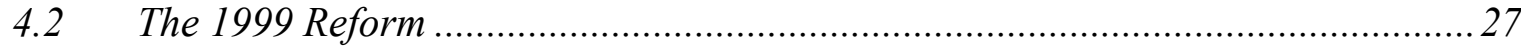

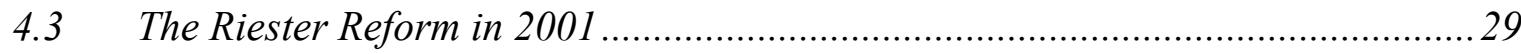

4.4 The PAYG pillar: reducing the replacement rate................................................. 30

4.5 The new funded pillar: introducing supplementary funded pensions .....................32

4.6 State promotion of occupational pension schemes................................................ 36

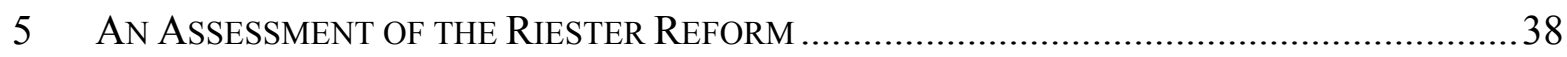

$5.1 \quad$ Will the "Riester" pensions actually take off? .......................................................... 38

$5.2 \quad$ Will the "Riester" pensions fill the pension gap? ................................................. 42

$5.3 \quad$ Will the "Riester" reform stabilize the German pension system? ………………... 44

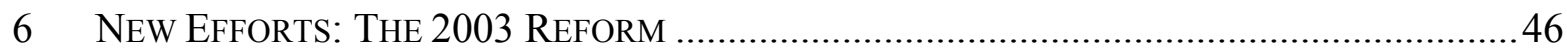

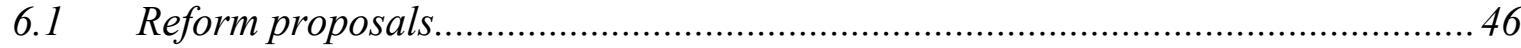

6.2 Long-term effects of the 2003 Reform proposals................................................. 49

$6.3 \quad$ Will the Rürup-proposals become law? ………………………......................... 51

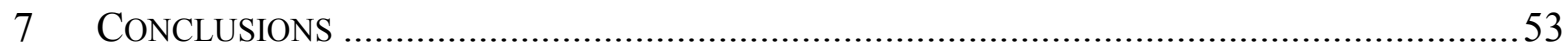




\section{The German Public Pension System:}

\section{How it Was, How it Will Be}

\section{by Axel H. Börsch-Supan and Christina B. Wilke}

\section{Introduction: a Historical Perspective}

The German pension system was the first formal pension system in the world, designed by Bismarck almost 120 years ago. It has been very successful in providing a high and reliable level of retirement income in the past at reasonable contribution rates, and it became a model for many social security systems around the world. It has survived two major wars, the Great Depression, and more recently, unification. It has been praised as one of the causes for social and political stability in Germany. Times have changed, however, and these days, this system is under severe pressure from population aging and adverse incentive effects. This paper addresses how this prototypical system emerged and where it will go. ${ }^{1}$

As opposed to other countries such as the United Kingdom and the Netherlands, which originally adopted a Beveridgian social security system that provided only a base pension, public pensions in Germany were from the start designed to extend the standard of living that was achieved during work life also to the time after retirement. Thus, public pensions are roughly proportional to labor income averaged over the entire life course and feature only few redistributive properties. The German pension system is therefore called „retirement insurance“ rather than „social security“ as in the United States, and workers used to understand their contributions as „insurance premia“ rather than „taxes“. The insurance character is strengthened by institutional separation: the German retirement insurance system is not part of the government budget but a separate entity. This entity is subsidized by the federal government. Rationale for this subsidy - about 30 percent of expenditures - are so-called "noninsurance benefits" such as benefits paid to German immigrants after opening the iron curtain.

\footnotetext{
1 Table 1 summarizes the history of the German public pension system.
} 
Any surplus, however, remains in the system. It is not transferable into a "unified budget" such as in the United States.

The German retirement insurance started as a fully funded system with a mandatory retirement age of 70 years when male life expectancy at birth was less than 45 years. Today, life expectancy for men is more than 75 years but average retirement age is less than 60 and even lower in East Germany. ${ }^{2}$ The system converted to a de facto pay-as-you-go system when most funds were invested in government bonds between the two world wars. After a long and arduous debate, the German Bundestag decided in 1957 to convert the system gradually to a pay-as-you-go scheme. The remainder of the capital stock was spent about 10 years later. Since then, the German system is purely pay-as-you-go with a very small reserve fund lasting less than 14 days of expenditures in Spring 2004.

A second historical reform took place in 1972. It made the German pension system one of the most generous of the world. The retirement behavior visible in current data is mainly influenced by the reform. The 1972 system is generous in two respects. First, the system has a high replacement rate, generating net retirement incomes that are currently about 70 percent of pre-retirement net earnings for a worker with a 45-year earnings history and average lifetime earnings. ${ }^{3}$ This is substantially higher than, e.g., the corresponding U.S. net replacement rate of about 53 percent. $^{4}$ The high initial level of public pensions was exacerbated by indexation to gross wages. Second, the 1972 reform abolished the mandatory retirement age of 65 years for those with a long service life ${ }^{5}$ in favor of a flexible choice during a "window of retirement" between age 63 and 65, with no actuarial adjustments. Adding to these very generous early retirement provisions were easy ways to claim disability benefits and low mandatory retirement ages for women and unemployed, further increasing the number of beneficiaries and extending the "window of retirement" between 60 and 65 .

\footnotetext{
${ }^{2}$ Average retirement age in a given year is the average age of those workers receiving public pension income for the first time. Source: VDR (2002).

3 This replacement rate is defined as the current pension of a retiree with a 45 -year average earnings history divided by the current average earnings of all dependently employed workers. It is different from the replacement rate relative to the most recent earnings of a retiring worker that are usually higher than the life-time average.

${ }^{4}$ Using the same replacement rate concept as in footnote 2.
} 
It is no surprise that the German public pension system is the single largest item in the social budget. In the year 2001, public pension expenditures amounted to some 200 billion Euro, representing 21 percent of public spending, and 11.8 percent of GDP. It is the second largest pension budget in the OECD, surpassed only by Italy (14.2 percent of GDP). It is more than 2.5 times as expensive as the U.S. Social Security System (4.4 percent of GDP). ${ }^{6}$

While the generosity of the German public pension system is considered a great social achievement, negative incentive effects and population aging are threatening the very core of the German pension system. While incentive effects are still arcane in the eyes of politicians and the electorate, population aging has become a "megatrend" in the popular debate. All industrialized countries are aging, however, Germany - together with Italy and Japan - will experience a particular dramatic change in the age structure of the population. The severity of the demographic transition has two causes: a quicker increase in life expectancy than elsewhere, partly due to a relatively low level still in the 1970s, and a more incisive baby boom/baby bust transition (e.g., relative to the United States) to a very low fertility rate of 1.3 children per women, only a bit higher than the rock-bottom fertility rate of 1.2 in Italy and Spain. Consequently, the ratio of elderly to working age persons - the old age dependency ratio - will increase steeply. According to the latest OECD projections, the share of elderly (aged 65 and above) will exceed a quarter of the population in 2030, and the German old age dependency ratio will almost double from 24.0 percent in 2000 to 43.3 percent in 2030 . $^{7}$ (See Figure 1)

\footnotetext{
${ }^{5}$ At least 35 years.

${ }^{6} \mathrm{OECD}(2001)$.

${ }^{7}$ OECD (2001). The OECD dependency ratio relates persons age 65 and older to persons between ages 15 and 64 .
} 


\section{Figure 1: Development of the Economic Dependency Ratio}

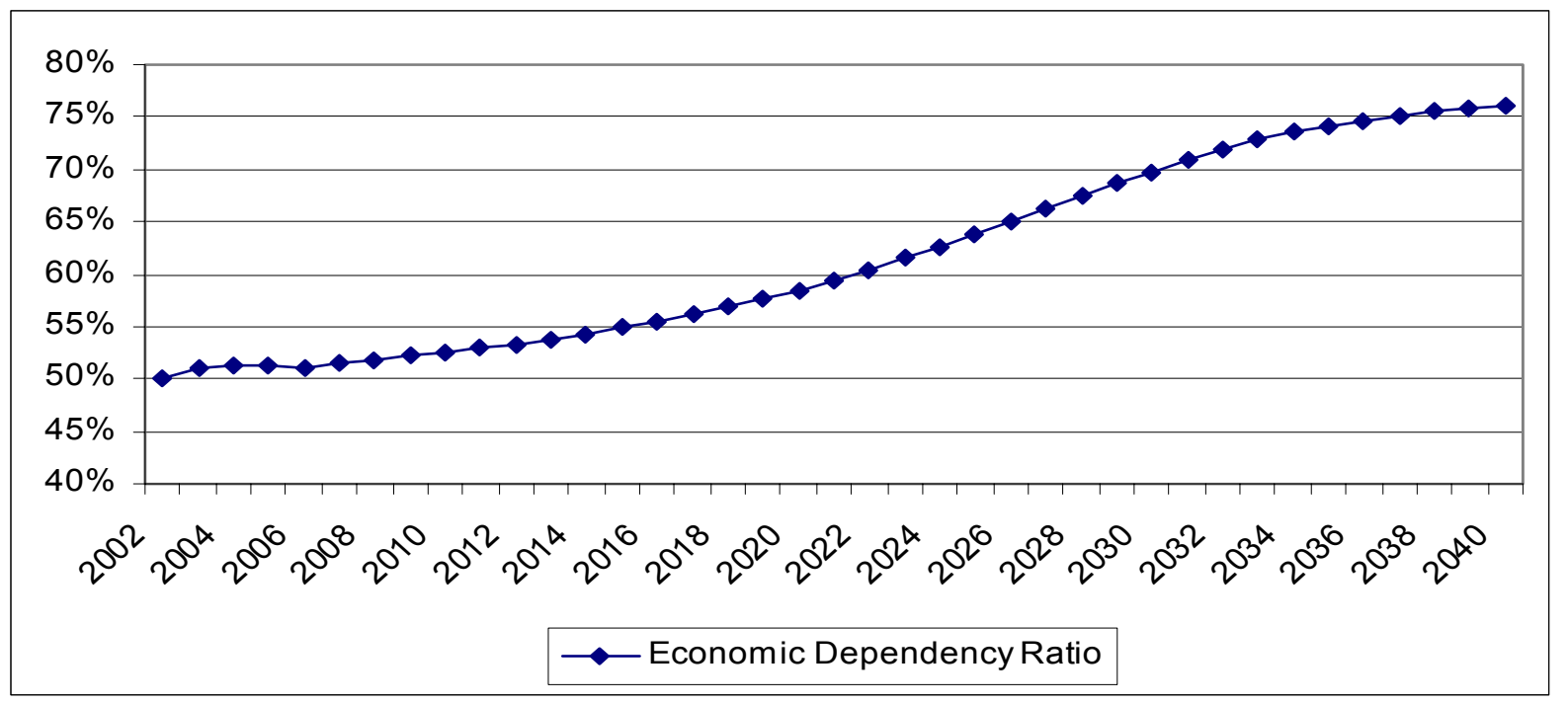

Note: Economic dependency ratio here as number of equivalence pensioners/ number of equivalence contributors. Source: Data supplied by the Rürup commission.

The increase in the dependency ratio has immediate consequences for a pay-as-you-go social insurance system because fewer workers have to finance the benefits of more recipients. The German social security contribution rate, in 2003 at 19.5 percent of gross income, was projected at the end of the 1980 s to exceed 40 percent of gross income at the peak of population ageing in 2035 if the accustomed replacement rates and the indication of pensions to gross income were maintained. ${ }^{8}$ This lead to a major pension reform in 1992 . This reform abolished the indexation of pensions to gross wages in favor of net wages. While this is still more generous than indexation to costs of living (such as in the U.S.), it was an important move away from the destabilizing feedback loop in which pensions increased when taxes and contributions heaved upwards. In addition, the 1992 reform introduced adjustments of benefits to early retirement age and abolished the generous "window of retirement" for all but those who have long service lifes. Benefit adjustments are, however, not fully actuarial. Changes in mandatory retirement ages are being introduced with a very long delay. First cohorts started experiencing these adjustments in 1997; the adjustments will be fully phased in by 2017 .

\footnotetext{
${ }^{8}$ Prognos (1989).
} 
It became quickly clear that the 1992 reform was too little and too late to put the German system on a stable and sustainable path. Another "parametric" reform introduced by the conservative government and due to become law in 1999 failed after the change in government in 1998. As a remarkable irony in politics, the social democratic secretary of labor Walter Riester successfully passed a major reform bill through parliament in 2001. This reform bed farewell to the pure pay-as-you-go system and introduced a multipillar pension system with a small but growing funded pillar. The new system will be fully phased in about 2050, but its main implications will be felt from 2011 onwards.

Future reforms are likely. ${ }^{9}$ None of the reforms so far touched the normal retirement which is at age 65. This may come as a surprise, since in the light of a prolonged life span, increasing the active part of it appears to be a rather natural reform option, in particularly since it simultaneously increases the number of contributors and decreases the number of beneficiaries and because age-specific morbidity rates appear to have shifted in line with mortality. ${ }^{10}$ As noted before, average, median and modal retirement age was about 60 years in 2002, the earliest eligibility age for old-age pensions and more than 5 years younger than the so-called "normal" retirement age in Germany. In late fall of 2002, the government established a reform commission for the "Sustainability in Financing the Social Insurance Systems", popularly called "Rürup commission". ${ }^{11}$ It has delivered concrete proposals in August 2003. Further cuts in the replacement rate of the pay-as-you-go pillar and an increase in the normal retirement age are two important elements of the new reform package.

This paper describes the current reform process. It is structured as follows. Part A (Sections 2 and 3) describes the institutional background for private sector and civil servants' pensions as they shaped the retirement behavior from 1972 until the end of the nineties. Part B (Sections 4, 5 and 6) describes and assesses the past and current reform process, culminating in the "Riester reform" of 2001 and continuing now with the efforts of the Rürup commission. Section 7 concludes with the question whether the 1992-2001 reforms and the current reform proposals

\footnotetext{
9 See Börsch-Supan (1998, 2000a) and Schnabel (1998) for descriptions of the problems, and Birg and BörschSupan (1999) and Börsch-Supan (2001) for concrete reform proposals.

${ }^{10}$ Cutler and Sheiner (1998).

${ }^{11}$ Named after its chairman. The commission's charge was to make proposals for pension, health and long-term care reform. One of the authors co-chaired the pension reform subcommission.
} 
will solve the problems of the German pension system. While there is further work to be done in order to stabilize the German pension system, we are optimistic: Substantial good work has been done, and we hope that some lessons can be drawn for other countries as well.

Table 1: The German Public Pension System from Bismarck until today

\begin{tabular}{|c|c|}
\hline $1889 / 1991$ & $\begin{array}{l}\text { Introduction of capital funded disability pension } \\
\text { Old age pension for workers age } 70 \text { and older } \\
\text { Employer and employee share contributions equally }\end{array}$ \\
\hline 1913 & Retirement at age 65 (white-collar workers only) \\
\hline 1916 & Decrease in retirement age for disability pensions from 70 to 65 \\
\hline $1921-23$ & Inflationary compensation \\
\hline 1923 & Retirement at age 65 (blue-collar workers) \\
\hline 1929 & Retirement at age 60 for elderly unemployed (white-collar workers only) \\
\hline 1957 & $\begin{array}{l}\text { Conversion into pay-as-you-go-system } \\
\quad \text { Contribution related pension benefits } \\
\quad \text { Safeguarding the standard of living in old age is main objective } \\
\quad \text { Dynamic benefits: indexed to gross wages and salaries } \\
\text { Normal retirement age } 65 \\
\text { Retirement at age } 60 \text { for elderly unemployed (blue-collar workers) } \\
\text { Retirement for women at age } 60\end{array}$ \\
\hline 1968 & Pure pay-as-you-go-system with minimum reserves for three months \\
\hline 1972 & $\begin{array}{l}\text { Public retirement insurance system open for all citizens (self-employed, } \\
\text { housewives) } \\
\text { Ex post payment of contributions becomes possible } \\
\text { Flexible early retirement age for insured with a long service life (63) and } \\
\quad \text { disabled persons }(60) \\
\text { New minimum pension mechanism }\end{array}$ \\
\hline 1977 & Pension splitting option for divorced couples \\
\hline 1978 & Minimum reserves are reduced to one month \\
\hline 1986 & $\begin{array}{l}\text { Benefits for child education (usually one year of service life) } \\
\text { Equal treatment for men and women regarding survivor's pensions }\end{array}$ \\
\hline 1992 & $\begin{array}{l}\text { Integration of East Germany } \\
\text { Indexing of pensions to net instead of gross wages and salaries } \\
\text { Step-wise increase of retirement ages for unemployed, disabled and women } \\
\text { Introduction of actuarial adjustments for early retirement } \\
\text { Significant reduction in years of education counting towards service life } \\
\text { Benefits for child education are raised to three years of service life }\end{array}$ \\
\hline
\end{tabular}




\begin{tabular}{ll}
\hline 1998 & Value added tax is increased in order to stabilize contributions to the GRV \\
& Introduction of the demographic factor \\
\hline 1999 & Introduction of demographic factor is revoked \\
Early retirement options for women and unemployed are restricted \\
Early retirement only for the long-insured and with benefit adjustments \\
Exceptions for disabled persons \\
Ecological tax is increased in order to stabilize contributions to the GRV \\
Transition to multi-pillar pension system ("Riester reform") \\
Reduction of first pillar pensions through modified gross indexation \\
Strengthening of capital funded second and third pillars by subsidies \\
and tax relief \\
Redefinition of "disability" \\
Further allowances for child education \\
Higher value in terms of recorded years of service life \\
Additive recording of employment becomes possible \\
Bonus for part-time employment \\
Reform of survivors pensions \\
Expansion of eligible income base \\
Reduction of survivor's pension benefits \\
Introduction of a child bonus \\
Optional pension splitting for married couples
\end{tabular}

Source: Authors' compilation. 


\section{Part A: The German Public Pension System How it Was}

The core of the German public pension system provides pensions to all private and public sector dependent employees, excluding civil servants and self-employed. We simply and somewhat loosely refer to this core system as "public pensions" or "private sector pensions" and describe it in section 2. In addition, civil servants - about 7 percent of the workforce have their own pay-as-you-go system which we describe in section 3. Self-employed - about 9 percent of the work force - can participate in the public system (some trade associations make this mandatory; about two-thirds participate) or self-insure (about 3 percent of the labor force). We largely ignore their special status in our description.

\section{Private Sector Pensions}

The German "public retirement insurance" ("Gesetzliche Rentenversicherung", GRV) covers about 85 percent of the German workforce. ${ }^{12}$ Most of these are private sector workers but the GRV also includes those public sector workers who are not civil servants. For the average German retiree, occupational pensions do not play a major role in providing old-age income. Neither do individual retirement accounts, but there are important exceptions from this general picture. Broadly speaking, the German pension system - as it was created in 1972 and as it shapes the current retirees' income - is a monolith. This will change due to the reform described in Part B. Some typical features of the German system, however, such as the benefit formula strictly linked to lifetime income and the resulting minor role of redistribution in the German pension system, will remain after the recent reforms.

\subsection{Coverage and contributions}

The German public pension system features a very broad mandatory coverage of workers. Only the self-employed and, until 1998, workers with earnings below the official minimum earnings

\footnotetext{
12 This and the following section are updated versions of Börsch-Supan, Schnabel, Kohnz and Mastrobuoni
} (2002). 
threshold („Geringfügigkeitsgrenze,“ 15 percent of average monthly gross wage; below this threshold are about 5.6 percent of all workers) are not subject to mandatory coverage.

Roughly 70 percent of the budget of the German public retirement insurance is financed by contributions that are administrated like a payroll tax, levied equally on employees and employers. Total contributions in 2003 are 19.5 percent of the first 5,100 Euro of monthly gross income (upper earnings threshold, „Beitragsbemessungsgrenze,“ about twice the average monthly gross wage). ${ }^{13}$ Technically, contributions are split evenly between employees and employers. The contribution rate has been steadily rising since the late 1960 s, and the upper earnings threshold has been used as an additional financing instrument. It has increased considerably faster than wage growth.

Private sector pension benefits are essentially tax-free. Pension beneficiaries do not pay contributions to the pension system and to unemployment insurance. However, pensioners have to pay the equivalent of the employees' contribution to the mandatory health and longterm care insurance. The equivalent of the employers' contribution to health insurance is paid by the pension system.

The remaining approximately 30 percent of the social security budget are financed by earmarked indirect taxes (a fixed fraction of the value-added tax and the new "eco-tax" on fossil fuel) and a subsidy from the federal government. The subsidy is also used to fine-tune the pay-as-you-go budget constraint because the system has a reserve of only about 14 days worth of benefits expenditures (August 2003). As opposed to a "unified budget" such as in the U.S., transfers can be made from the government to retirement insurance, but not in reverse.

\subsection{Benefit types}

The German public retirement insurance provides old-age pensions for workers aged 60 and older, disability benefits for workers below age 60 which are converted to old-age pensions latest at age 65 , and survivor benefits for spouses and children. In addition, pre-retirement (i.e.,

\footnotetext{
${ }^{13}$ About 20 percent less in East Germany. 1 Euro has a purchasing power of approximately 1 US-\$. (current exchange rate, September 2003, is 1.1 Euro per 1 US-\$.)
} 
retirement before age 60) is possible through several mechanisms using the public transfer system, mainly unemployment compensation. We begin by describing old-age pensions.

\section{Eligibility for benefits and retirement age for old age pensions}

Eligibility for benefits and the minimum retirement age depend on which type of pension applies to the worker. The German public retirement insurance distinguishes five types of oldage pensions, corresponding to normal retirement and four forms of early retirement. Table 2 shows the minimum retirement age for all pension types as it was until the late nineties.

Table 2: Old-Age Pensions (1972 Legislation)

\begin{tabular}{lcccc}
\hline Pension type & $\begin{array}{c}\text { Retire- } \\
\text { ment age }\end{array}$ & $\begin{array}{c}\text { Years of } \\
\text { service }\end{array}$ & Additional conditions & $\begin{array}{c}\text { Earnings } \\
\text { test }\end{array}$ \\
\hline A Normal & 65 & 5 & & No \\
\hline $\begin{array}{l}\text { B: Long service life } \\
\text { (,flexiblec) }\end{array}$ & 63 & 35 & Yes \\
\hline C: Women & 60 & 15 & 10 of those after age 40 & Yes \\
\hline D: Older disabled & 60 & 35 & $\begin{array}{l}\text { Loss of at least } 50 \text { percent } \\
\text { earnings capability }\end{array}$ & (Yes) \\
\hline E: Unemployed & 60 & 15 & $\begin{array}{l}\text { 1.5 to 3 years of unemployment } \\
\text { (has changed several times) }\end{array}$ & Yes \\
\hline
\end{tabular}

Notes: This legislation was changed in the reform of 1992. Changes became first effective between 1997 and 2001 (for the different pension types) and will be gradually phased in until 2017. Almost all changes will be effective by 2011 .

This complex system was introduced by the 1972 social security reform. One of the key provisions was the introduction of "flexible retirement" after age 63 with full benefits for workers with a long service history. In addition, retirement at age 60 with full benefits was possible for women, unemployed, and older disabled workers. "Older disabled workers" referred to those workers who cannot be appropriately employed for health or labor market reasons and are age 60 or older. There were three possibilities to claim old age disability benefits. One has to (1) be physically disabled to at least 50 percent, or (2) pass a strict 
earnings test, or (3) pass a much weaker earnings test. The strict earnings test is passed if the earnings capacity is reduced below the minimum earnings threshold for any reasonable occupation (about 15 percent of average gross wage) ("erwerbsunfähig," EU). The weaker earnings test is passed when no vacancies for the worker's specific job description are available and the worker has to face an earnings loss of at least 50 percent when changing to a different job ("berufsunfähig," $B U$ ). As opposed to the disability insurance for workers below age 60 (see below), full benefits are paid in all three cases. This definition of disability and the associated earnings tests have been changed as a part of the Riester Reform in 2001 and the term disability now applies in general only to health and no longer to labor market reasons. ${ }^{14}$

Due to the 1992 social security reform and its subsequent modifications, the age limits of early retirement will gradually be raised to age 65 . These changes will be fully phased in by the year 2017, almost all changes, however, will be effective by 2011. The only distinguishing feature of types B and C of "early retirement" will then be the possibility to retire up to three years earlier than age 65 if a sufficient number of service years (currently 35 years) has been accumulated. As opposed to the pre-1992 regulations, benefits will be adjusted to a retirement age below age 65 in a fashion that will be described below.

\section{Old age pension benefits}

Benefits are strictly work-related and quite close to actuarially fair and free from redistribution, very different from the United States. ${ }^{15}$ The German system does not have benefits for spouses like in the United States. ${ }^{16}$ Benefits are computed on a lifetime basis and adjusted according to the type of pension and the retirement age. They are the product of four elements: (1) the socalled "earning points" (EP) that reflect the employee's relative earnings position, (2) the employee's years of service life (SY), (3) adjustment factors (AF) for pension type and (since the 1992 reform) retirement age, and (4) a macroeconomic reference pension value - the socalled "current pension value" (PV). The annual value of a pension $\mathrm{P}_{t, i}$ in year $\mathrm{t}$ for pensioner $\mathrm{i}$ is thus computed as follows:

\footnotetext{
${ }^{14}$ There are still exceptions as a consequence of case law spoken by the labor courts.

15 The main redistribution occurs through early retirement, see below.
} 


$$
\mathrm{P}_{\mathrm{t}, \mathrm{i}}=\mathrm{EP}_{\mathrm{i}} * \mathrm{SY}_{\mathrm{i}} * \mathrm{AF}_{\mathrm{i}} * \mathrm{PV}_{\mathrm{t}}
$$

The first three factors make up the "personal pension base" while the fourth factor determines the income distribution between the current workers and the stock of pensioners. The combination of the first three factors is unique for the German pension system and provides a strong actuarial link between lifetime income and pension benefits. Hence, redistribution plays only a minor role in the German pension system. The current reform process will not change this. Rather, the cost-cutting reforms since 1992 all concentrate on the fourth factor and redefine how changes in the average earnings by workers affect the average pension. Note the formula is applied to the entire stock of pensioners, not only to new entrants. Hence, the German system is time, not cohort-oriented. This crucial difference to other pension systems notably the Italian one - makes reform easier if equal burden sharing is an agreed principle among voters.

Earning points (EP). They are expressed as a multiple of the average annual contribution (roughly speaking, the relative income position) in each historical working year: one EP corresponds to average earnings in that year, $0.5 \mathrm{EP}$ to 50 percent of average earnings, and 2 EP to earnings twice as large as average earnings in that year.

Years of service life (SY). They comprise years of active contributions plus years of contributions on behalf of the employee and years that are counted as service years even when no contributions were made at all. These include, for instance, years of unemployment, years of military service, three years for each child's education for one of the parents, some allowance for advanced education etc. Unlike to many other countries, there is neither an upper bound of years entering the benefit calculation, nor can workers choose certain years in their earnings history and drop others.

Adjustment factors (AF). This factor is one for a normal old-age pension. Before 1999, it included several adjustments to disability pensions. Depending on the type of disability pension, AF took on values between 0.25 and 1. Since about 2000, AF has a second element.

\footnotetext{
${ }^{16}$ There are, of course, survivor benefits.
} 
For old-age pensions, it represents the adjustment of benefits to retirement age which are currently being phased-in, see Table 3 .

Current pension value (PV). This is the crucial link between worker's earnings and pensioners' benefits. The PV is indexed to the annual changes in the level of wages and salaries net of pension contributions and thus enables pensioners to share in the rising prosperity generated by the economy. This link between changes in workers' earnings and pensioners' benefits is specified as a mathematical "benefit indexation formula". Typical for the philosophy of the German public pension system, this mathematical formula is verbatim part of the law.

In the past, the stability of this formula has created a sense of actuarial fairness, so that workers perceived the contributions largely as insurance premia. However, this has changed when the formula was altered several times since 1992. Until 1992 pensions were indexed to gross wages, between 1992 and 1998 to net wages and in 1999 and 2000 to the respective previous year's rate of inflation. The perception of discretionary changes, and the prospect of further reductions in the pension generosity has led to a great deal of dissatisfaction with the German pension system, in particularly among younger workers. Surveys show that by 2001, contributions were largely perceived as taxes. ${ }^{17}$ Nonetheless and inevitably, changes in the benefit indexation formula are one of the main elements of the current cost-cutting reforms. The indexation to the average net labor income from 1992 until 1998 solved some of the problems that were created by indexation to gross wages until $1992 .^{18}$

The German public pension system has provided a generous benefit level for middle-income earnings. The net replacement rate for a worker with 45 earning points was 70.5 percent in 1998. ${ }^{19}$

\footnotetext{
${ }^{17}$ Boeri, Börsch-Supan and Tabellini (2001).

${ }^{18}$ Nevertheless, wage rather than cost of living indexation makes it impossible to finance the retirement burden by productivity gains.

${ }^{19}$ The official government computations such as the above official replacement rate (,Rentenniveau“ $)$ assume a 45-year contribution history for what is deemed a „,normal earnings history“ (,Eckrentner"). In fact, the average number of years of contributions is about 38 years. In turn, however, many pensioners with short earnings histories had above-average earnings. Hence, about half of all entrants have 45 earnings points or more.
} 
Unlike to the U.S., the German pension system has only little redistribution as is obvious from the benefit computation. ${ }^{20}$ The low replacement rates for high incomes result from the upper limit to which earnings are subject to social security contributions - they correspond to a proportionally lower effective contribution rate. The only element of redistribution in the individual benefit computation formula was introduced in 1972 when this multiple could not fall below 75 percent for contributions before 1972 provided a worker had a service life of at least 35 years. A similar rule was introduced in the 1992 reform: for contributions between 1973 and 1992, multiples below 75 percent are multiplied by 1.5 up to the maximum of 75 percent, effectively reducing the redistribution for workers with income positions below 50 percent. In 2001, this system has been abolished in favor of a guaranteed minimum pension (“Grundsicherung") at the level of social assistance plus 15 percent.

Before 1992, adjustment of benefits to retirement age was only implicit via SY. Because benefits are proportional to the SY, a worker with fewer SY will get lower benefits. With a constant income profile and $40 \mathrm{SY}$, each year of earlier retirement decreased pension benefits by 2.5 percent, and vice versa. The 1992 social security reform is changing this gradually, see Section 4.2 and Figure 5. Age 65, the "normal retirement age", is thus acting as the "pivotal age" for benefit computations. For each year of earlier retirement, up to five years and if the appropriate conditions in Table 2 are met, benefits will be reduced by 3.6 percent (in addition to the effect of fewer service years). The 1992 reform also introduced rewards for later retirement in a systematic way. For each year of retirement postponed past the mandatory retirement age, the pension is increased by 5 percent in addition to the "natural" increase by the number of service years.

Table 3 displays the retirement-age-specific adjustments for a worker who has earnings that remain constant after age 60 . The table relates the retirement income for retirement at age 65 (normalized to 100 percent) to the retirement income for retirement at earlier or later ages, and compares the implicit adjustments after 1972 with the total adjustments after the 1992 social

\footnotetext{
${ }^{20}$ See Casmir (1989) for a comparison.
} 
security reform is fully phased in. As references, the table also displays the corresponding adjustments in the United States and actuarially fair adjustments at a 3 percent discount rate. ${ }^{21}$

Table 3: Adjustment of Public Pensions by Retirement Age

Pension as a percentage of the pension that one would obtain if one had retired at age 65

\begin{tabular}{cccccc}
\hline & \multicolumn{2}{c}{ Germany } & \multicolumn{2}{c}{ United States } & Actuarially \\
\hline Age & pre-1992 $^{\text {a) }}$ & post-1992 $^{\mathbf{b})}$ & pre-1983 $^{\mathbf{c})}$ & post-1983 $^{\mathbf{d})}$ & fair $^{\mathbf{e})}$ \\
\hline 62 & 100.0 & 89.2 & 80.0 & 77.8 & 80,5 \\
63 & 100.0 & 92.8 & 86.7 & 85.2 & 86,3 \\
64 & 100.0 & 96.4 & 94.4 & 92.6 & 92,8 \\
65 & 100.0 & 100.0 & 100.0 & 100.0 & 100,0 \\
66 & 107.2 & 106.0 & 103.0 & 105.6 & 108,1 \\
67 & 114.4 & 112.0 & 106.0 & 111.1 & 117,2 \\
68 & 114.4 & 118.0 & 109.0 & 120.0 & 127,4 \\
69 & 114.4 & 124.0 & 112.0 & 128.9 & 139,1 \\
\hline
\end{tabular}

Notes: a) GRV 1972-1992. b) GRV after 1992 reform has fully phased in (after 2011). c) US-Social Security (OASDHI) until 1983. d) US-Social Security after 1983 Social Security Reform has fully phased in. e) Evaluated at a 3 percent discount rate, 1992/94 mortality risks of West-German males and an annual increase in net pensions of 1 percent.

Sources: Börsch-Supan and Schnabel (1999).

While neither the German nor the American system were actuarially fair prior to the reforms, the public retirement system in Germany as enacted in 1972 was particularly distortive. There was less economic incentive for Americans to retire before age 65 and only a small disincentive to retire later than at age 65 after the 1983 US. Reform, while the German social security system at those times tilted the retirement decision heavily towards the earliest retirement age applicable. The 1992 reform has diminished but not abolished this incentive effect, as a comparison of the sixth and the third column of Table 3 shows.

\footnotetext{
${ }^{21}$ The actuarially fair adjustments equalize the expected social security wealth for a worker with an earnings history starting at age 20 . A higher discount rate yields steeper adjustments.
} 


\section{Disability and survivor benefits}

The contributions to the German retirement insurance also finance disability benefits to workers of all ages and survivor benefits to spouses and children. In order to be eligible for disability benefits, a worker must pass one of the two earnings tests described earlier for the old-age disability pension. If the stricter earnings test is passed, full benefits are paid (,Erwerbsunfähigkeitsrente,“ EU). If only the weaker earnings test is passed and some earnings capability remains, disability pensions before age 60 are only two-thirds of the applicable old age pension (,Berufsunfähigkeitsrente,“ $B U$ ). In the 1970s and early 1980s, the German jurisdiction has interpreted both rules very broadly, in particular the applicability of the first rule. Moreover, jurisdiction also overruled the earnings test during disability retirement. This lead to a share of $E U$-type disability pensions of more than 90 percent of all disability pensions. Because both rules were used as a device to keep unemployment rates down, their generous interpretation has only recently, in the context of the Riester reform, lead to stricter legislation. ${ }^{22}$

Survivor pensions are 60 percent (after 2001: 55 percent) of the husband's applicable pension for spouses that are age 45 and over or if children are in the household (,große Witwenrente ${ }^{6)}$, otherwise 25 percent (,kleine Witwenrente“). Survivor benefits are therefore a large component of the public pension budget and of total pension wealth. Certain earnings tests apply if the surviving spouse has her own income, e.g., her own pension. This is only relevant for a very small (below 10 percent) share of widows. As mentioned before, the German system does not have a married couple supplement for spouses of beneficiaries. However, most wives acquire their own pension by active (own employment) and passive contributions (years of advanced education and years of child education).

\subsection{Pre-retirement}

In addition to benefits through the public pension system, transfer payments (mainly unemployment compensation) enable what is referred to as ,pre-retirement“. Labor force exit before age 60 is frequent: about 45 percent of all men call themselves ,retired“ at age 59. Only

\footnotetext{
${ }^{22}$ See Riphahn (1995) for an analysis of disability rules.
} 
about half of them retire because of disability; the other 50 percent make use of one of the many official and unofficial pre-retirement schemes.

Unemployment compensation has been used as pre-retirement income in an unofficial scheme that induced very early retirement. Workers entered such a scheme much earlier than age 60 and were paid a negotiable combination of unemployment compensation and a supplement or severance pay. A pension of type E (see Table 2) could then start at age 60. As the rules of pensions of type E and the duration of unemployment benefits changed, so did the "unofficial" retirement ages. Age 56 was particularly frequent in West Germany because unemployment compensation is paid up to three years for elderly workers; it is followed by the lower unemployment aid. Earlier retirement ages could be induced by paying the worker the difference between the last salary and unemployment compensation for three years; and for further years the difference between the last salary and unemployment aid - it all depended on the so-called ,social plan“ which a firm would negotiate with the workers before restructuring the work force.

In addition, early retirement at age 58 was made possible in an official pre-retirement scheme ("Vorruhestand"), in which the employer received a subsidy from the unemployment insurance if a younger employee was hired. While the first (and unofficial) pre-retirement scheme was very popular and a convenient way to overcome the strict German labor laws, few employers used the (official) second scheme.

\subsection{Retirement behavior}

The retirement behavior of entrants into the German public retirement insurance system closely reflects changes in the institutional environment. This is an important finding. It is summarized by Figure 2. It shows the uptake of the various pathways to old-age pensions ${ }^{23}$, including the disability pathway, (adding to 100 percent on the vertical axis) and their changes over time (marked on the horizontal axis), mostly in response to benefit adjustments and administrative rule changes, in particularly the tightening of the disability screening process. The fraction of those who enter retirement through a disability pension has declined and was 29 percent in

\footnotetext{
${ }^{23}$ See Jacobs, Kohli and Rein (1990) for this concept.
} 
1998. Only about 20 percent of all entrants used the "normal" pathway of an old-age pension at age 65 .

Figure 2: Pathways to Retirement, 1960-2002
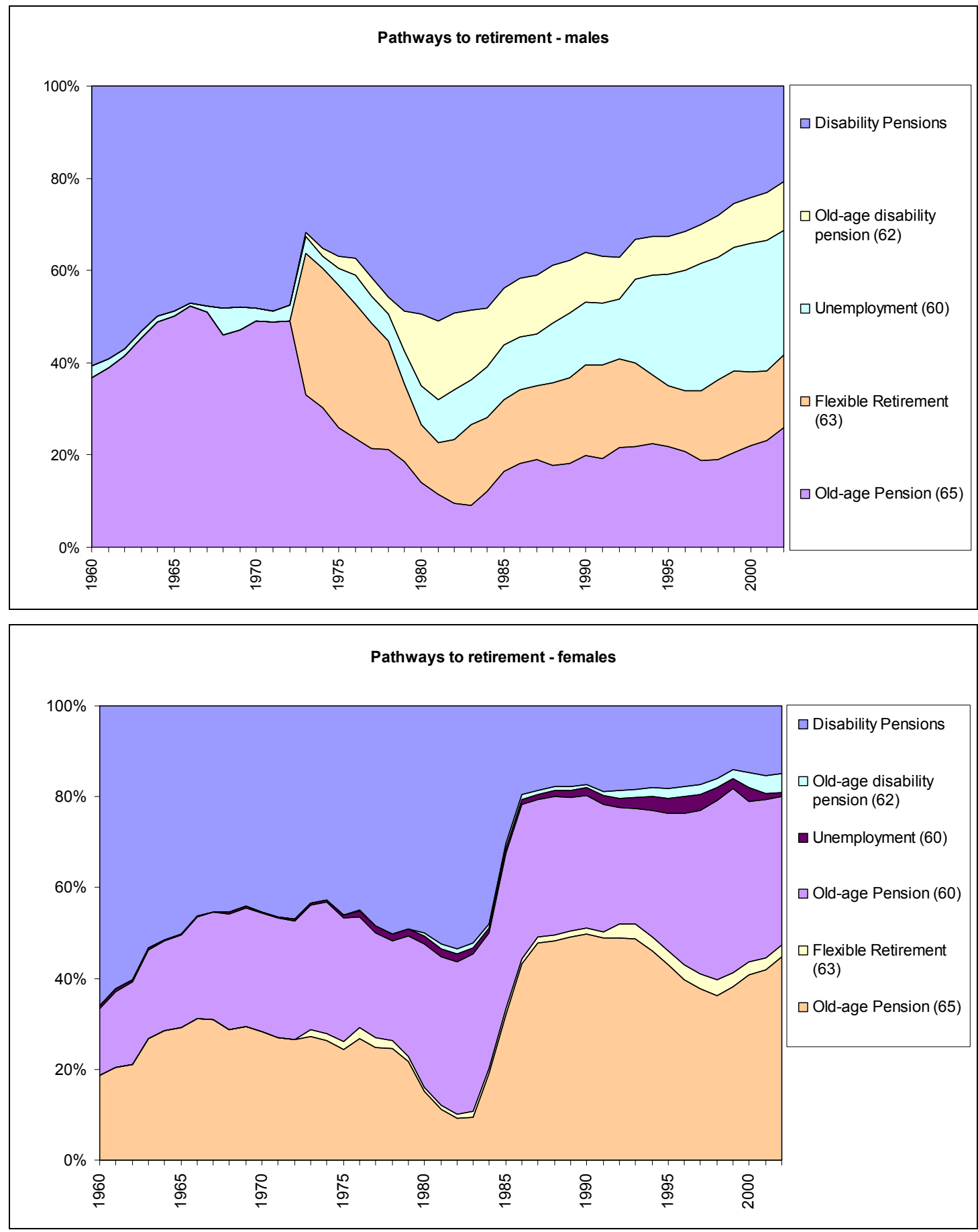

Source: Verband deutscher Rentenversicherungsträger (VDR), Die Rentenversicherung in Zeitreihen. 
The average retirement age in 1998 was 59.7 years for men and 60.7 years for women. These numbers refer to West Germany. In the East, retirement age was 57.9 years for men and 58.2 years for women. The average retirement age has dramatically declined after the 1972 reform, see Figure 3. We interpret this as a clear sign of a policy reaction, in particular, since it does not coincide with labor demand effects generated by the rise in unemployment. ${ }^{24}$ The most popular retirement age is age 60 , see Figure 4 . The close correspondence to the pathways in Table 2 is another clear sign for a behavioral response to the incentives created by the pension system, and in particular the change of the peaks and spikes after the 1972 reform. $^{25}$

\section{Figure 3: Average Retirement Age, 1960-1995}

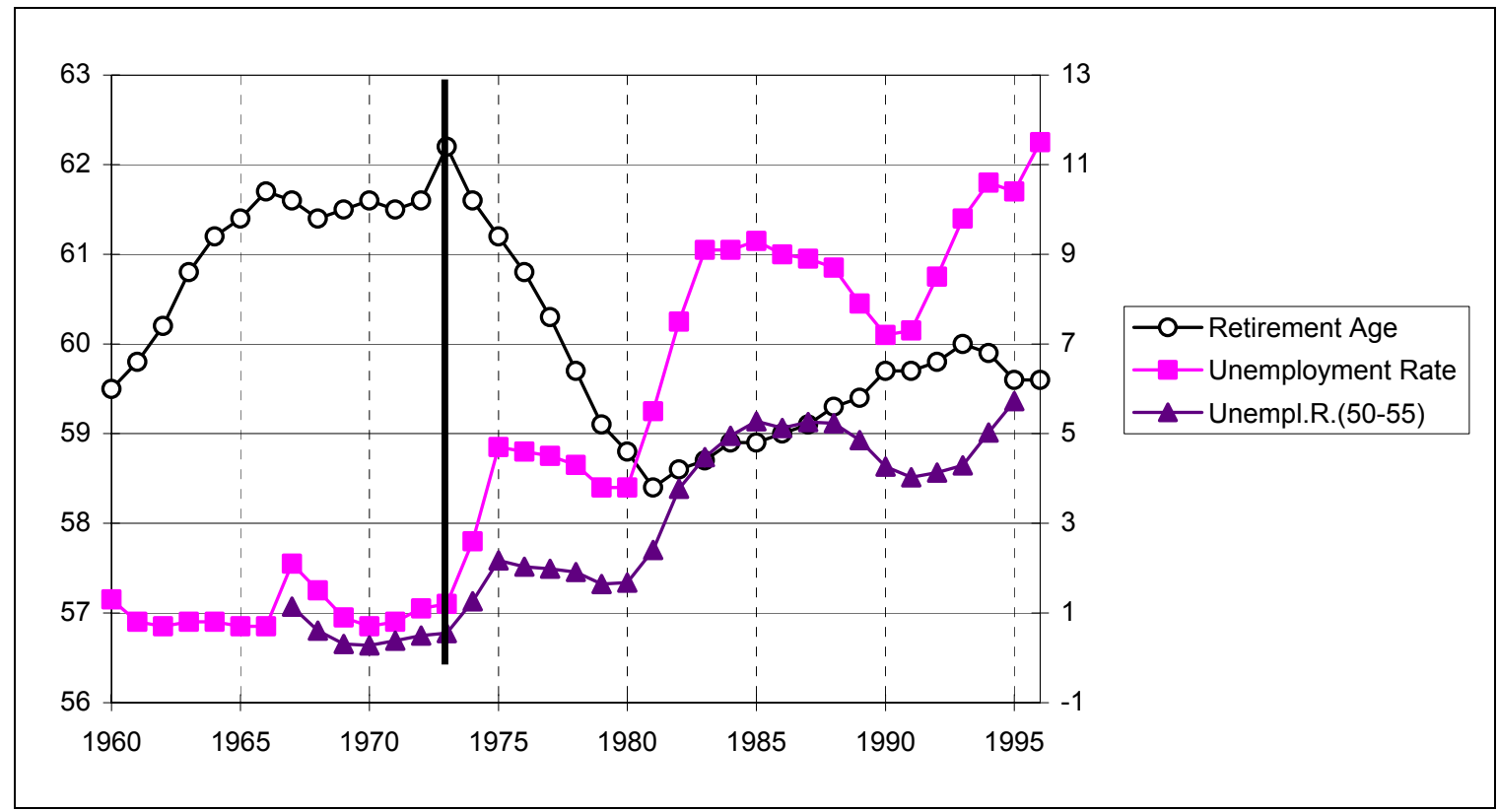

Note: „Retirement Age“ is the average age of all new entries into the public pension system. „Unemployment rate“ is the general national unemployment rate. „Unempl.R.(50-55)“ refers to male unemployed age 50-55. Source: VDR 1997 and BMA 1997.

\footnotetext{
${ }^{24}$ See Börsch-Supan and Schnabel (1998).

${ }^{25}$ See Börsch-Supan (2000c).
} 
Figure 4: Distribution of Retirement Ages, 1970, 1975, 1980 and 1995

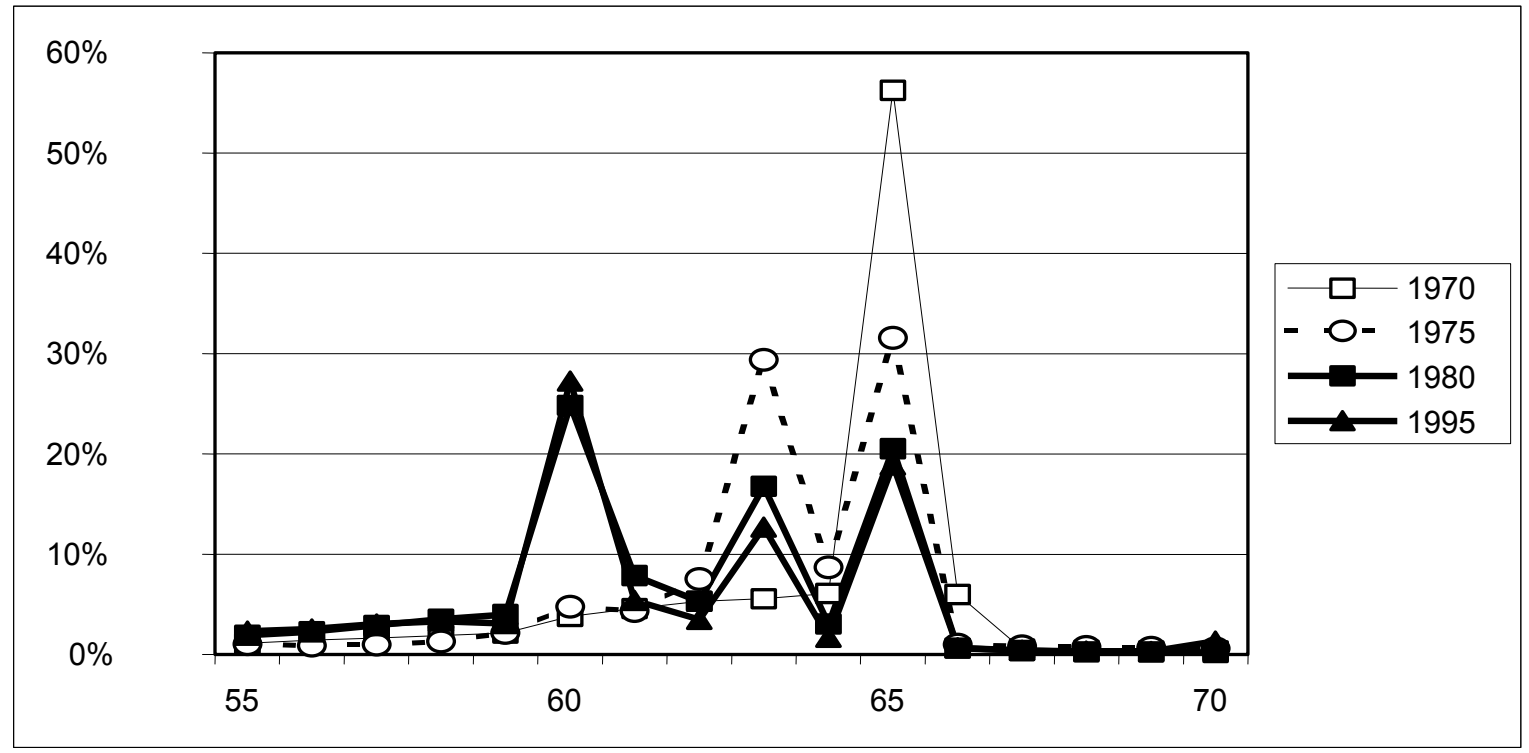

Source: Verband deutscher Rentenversicherungsträger (VDR), 1997.

\section{Civil Service Pensions}

About 90 percent of the German labor force is enrolled in the system described in section 2. About one third of the self-employed are self insured ( 3 percent of the labor force), and another 7 percent are civil servants. Civil servants are exempted from the public pension system described in section 2. They do not pay explicit contributions for their pensions as the other employees in the private and public sectors do. ${ }^{26}$ Instead, the "gross" wage for civil servants is lower than the gross wage of other public sector employees with a comparable education. Civil servants acquire pension claims that are considerably more generous than those described in the previous section, and they have rather distinctive early retirement incentives. While the private sector pensions described above have undergone an incisive reform process (see Part B), civil servants have largely been protected from benefit cuts so far.

\footnotetext{
${ }^{26}$ Civil servants are also exempt from unemployment insurance contributions, since civil servants have a life-time job guarantee. The government pays a certain fraction of health expenses of the civil servant and his or her dependents (ranging from 50 to 80 percent). The rest has to be covered by private insurance.
} 


\subsection{Eligibility: pathways to retirement for civil servants}

There are three pathways for civil servants: the standard, the early, and the disability retirement option. The standard retirement age is 65 . Before July 1, 1997 the early retirement age for civil servants was 62 and thus one year less than the early retirement age for workers with a long service life in the social security system. In 1997 early retirement age was raised to 63. Discount factors for early retirement are phasing in linearly between the years 1998 and 2003, and will reach 0.3 percentage points per month of early retirement, the same as in the private sector and substantially smaller than actuarially fair. ${ }^{27}$

Filing for disability is a third pathway to retirement for civil servants. In the case of disability a civil servant receives a pension which is based on his or her previous salary. The replacement rate depends on the number of service years reached before disability retirement and the number of service years that could potentially have been accumulated until age 60 . For those who did not reach the maximum replacement rate before disability, one additional year of service raises the replacement rate by only $1 / 3$ percentage point per year.

\subsection{Computation of civil servants' pensions}

The standard pension benefit for civil servants is the product of three elements: (1) the last gross earnings level, (2) the replacement rate as function of service years, and (3) the new adjustment factors to early retirement. There are three crucial differences between civil servants pensions and private sector benefits. First, the benefit base is gross rather than net income as it was in the private sector between 1992 and 1998. In turn, civil servants' pensions are taxed like any other income. Finally, the benefit base is the last salary rather than the lifetime average.

Last gross earnings level. Benefits are anchored to the earnings in the last position and then updated annually by the growth rate of the net earnings of active civil servants. If the last position was reached within the last two years before retirement, the pension is based on the previous, lower position. Due to the difference in the benefit base, gross pensions of civil

\footnotetext{
${ }^{27}$ Very specific rules apply to some civil servants. E.g., the regular retirement age for police officers is age 60 ; for soldiers it is even lower and depends on their rank.
} 
servants are approximately 25 percent higher (other things being equal) than in the private sector.

Replacement rate. The maximum replacement rate is 75 percent of gross earnings which is considerably higher than the official replacement rate of the private sector system which is around 70 percent of net earnings. The replacement rate depends on the years of service. High school and college education, military service, and other work in the public sector are also counted as service years. For retirement after June 1997 the college education credit is limited to 3 years.

Before 1992 the replacement rate was a non-linear function of service years. The replacement rate started at a value of 35 percent for all civil servants with at least 5 years of service. For each additional year of service between the $10^{\text {th }}$ and the $25^{\text {th }}$ year the increment was 2 percentage points. From the $25^{\text {th }}$ to the $35^{\text {th }}$ year the annual increment was one percent. Thus, the maximum replacement rate of 75 percent was reached with 35 service years under the old rule. This is much more generous than the private sector replacement rate of 70 percent which requires 45 years of service.

New adjustment factors to early retirement. For persons retiring after January 1, 1992 the replacement rate grows by 1.875 percentage points for each year of service. Thus, the maximum value is reached after 40 years of service. However, there are transitional modifications to that simple rule. First, civil servants who reach the standard retirement age (usually age 65) before January 1, 2002 are not affected at all. Second, for younger civil servants, all claims that have been acquired before 1992 are conserved. These persons gain one additional percentage point per year from 1992 on. All persons who have acquired 25 service years before 1992 have reached 65 percentage points and would also have gained only one additional point per year under the old rule. Only persons with less than 25 service years in 1991 can be made worse off by the reform. The new proportional rule only applies if it generates a higher replacement rate than the transitional rule.

The generosity of gross pensions received by civil servants vis-à-vis the private sector workers is only partially offset by the preferential tax treatment of private sector pensions. Since civil servants' pensions are taxed according to the German comprehensive income taxation, the net replacement rates of civil service pension recipients depends on their position in the highly 
progressive tax schedule. In general, the net replacement rate with respect to the pre-retirement net earnings is higher than 75 percent and thus considerably more generous than in the private sector.

\subsection{Incentives to retire for civil servants}

Currently, most civil servants reach the maximum replacement rate by the age of 54. Persons who have started to work in the public sector before the age of 23 have reached a replacement rate of 75 percent when taking into account the disability rules. This also holds for civil servants, who - like professors - receive lifetime tenure late in their life cycle. For those groups the starting age is usually set to age 21 . Additional years of service beyond the age of 54 increase pensions only if the civil servant is promoted to a position with a higher salary. Retirement incentives therefore strongly depend on promotion expectations.

For persons who cannot expect to be promoted after age 54 the pension accrual is zero or very small. For those who have already reached the replacement rate of 75 percent, the accrual of the present discounted pension wealth is negative. Since the replacement rate is 75 percent of the gross earnings in the last position before retirement, the negative accrual of postponing retirement by one year is simply 75 percent of the last gross earnings. This is equivalent to a 75 percent tax on earnings.

For persons who expect to climb another step in the hierarchy the gross wage increase is on average 10.5 percent. This raises the pension by approximately 10 percent. In order to cash in the higher pension, the civil servant has to defer retirement by at least one year. ${ }^{28}$ In this extreme case the social security wealth increases 10 percent through the effect of higher pensions and decreases by 5 percent through the effect of pension deferral. In this extreme case the pension accrual is positive. If the civil servant has to wait several years for the next promotion (or for the promotion to have an effect on pension claims) the accrual of working becomes negative; hence, it makes no financial sense to keep working.

\footnotetext{
${ }^{28}$ For the higher earnings to take effect on pensions it is usually required to work several years after the promotion.
} 


\subsection{Retirement behavior of civil servants}

The retirement behavior of civil servants reflects the very generous disability and early retirement rules. The average retirement age for civil servants in the year 1993 was age 58.9 and thus about one year lower than in the private sector. Disability is the most important pathway to retirement for civil servants: 40 percent of those who retired in the year 1993 used disability retirement. Almost one third used the early retirement option at the age of 62 . Only about 20 percent of civil servants retired at the regular retirement age of 65 . 


\section{Part B: The German Public Pension System How it Will Be}

\section{The German Pension Reform Process}

After the remarkable expansion of the German pension system after 1972, four dates mark the pension reform process in Germany: 1992 and 2001 have seen two major pension reforms, with a further strengthening of the 2001 reform in 2004. A reform due to become law in 1999 failed after federal elections, but some elements are being resurrected in the 2004 reform. In addition, there was a constant flurry of smaller adjustments in between.

\subsection{The 1992 Reform}

The main changes in the 1992 reform were to anchor benefits to net rather than to gross wages. This implicitly has reduced benefits since taxes and social security contributions have increased, reducing net relative to gross wages. This mechanism will become particularly important when population aging will speed up since it implies an implicit mechanism of burden sharing between generations.

The second important element in the 1992 reform was the introduction of "actuarial" adjustments to benefits to retirement age and an increase in the "normal" retirement ages for all pension types, except disability pensions (age 63), to 65. These changes have been described in Subsection 2.2. and are displayed in Figure 5 (including their 1999 speed-up). They will reduce incentives to retire early, although the "actuarial" adjustments are not actuarially fair in a mathematical sense except for very low discount rates.

\subsection{The 1999 Reform}

The 1999 pension reform was supposed to lower the replacement rate according to a prespecified so-called "demographic factor", a function of life expectancy plus several correction factors. It was revoked after the change of government in 1998. A side effect of this reform, which was not revoked, was a gradual change of eligibility ages for pensions for women and 
unemployed (types $\mathrm{C}$ and $\mathrm{E}$ in Table 2) from age 60 to age 65. This change will be fully implemented by 2017 and effectively leave a "window of retirement" for healthy workers only if they have at least 35 years of service. As opposed to Table 2, there will be no distinction between men and women (after the year 2015); unemployment-retirement will be abolished (after the year 2007); and part-time retirement (which was largely taken in two "blocks" of full-work and subsequent full-retirement) will be impossible (after the year 2007). Figure 5 depicts the new eligibility regulations and adjustment paths for the various pension types described before in Table 2. These changes were largely unnoticed by the population. They will change the effective retirement age by around 2 years from about age 60 to age 62 , see the projections by Berkel and Börsch-Supan (2003).

Figure 5: Retirement age with and without "actuarial" adjustments (1992 and 1999 reforms)

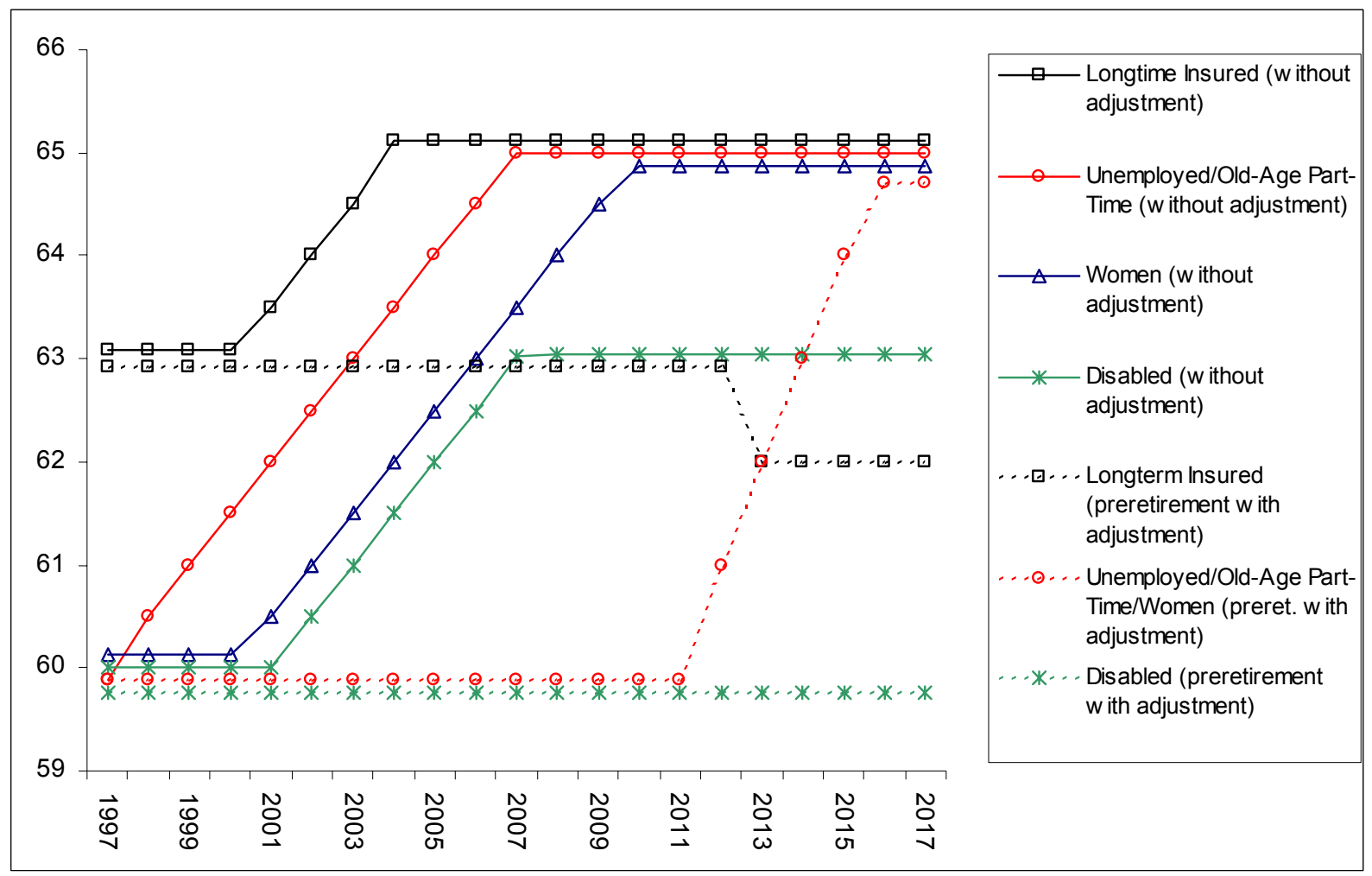

Source: Authors' compilation 


\subsection{The Riester Reform in $\mathbf{2 0 0 1}$}

On May 11, 2001 a new pension reform act was ratified in Germany, popularly referred to as the "Riester reform" after the then labor minister Walter Riester. The 2001 reform is a major change in the system. It will change the monolithic German system of old-age provision to a genuine multi-pillar system. The most important aspect of the reform, which came into effect on January 1,2002, is a partial substitution of pay-as-you-go financed pensions by funded pensions. The reform aimed to achieve three main objectives:

\section{(1) Sustainable contribution rates}

The key objective of the Riester reform was to stabilize contribution rates and thus (a) to limit further increases in non-wage labor costs and (b) to achieve a fairer balance of intergenerational burdens. The law actually states that contribution rates to the public retirement insurance scheme must stay below 20 percent until 2020 and below 22 percent until 2030 while the net replacement rate must stay above 67 percent. Failure must precipitate government action.

\section{(2) Secure the long-term stability of pension levels}

Pensions will be gradually reduced from the current level of 70 percent of average net earnings to around 67-68 percent by the year 2030. At the same time, however, the Riester reform changed the computational procedure for the reference earnings, now subtracting a fictitious 4 percent of gross earning to be invested into the new funded supplementary private pensions. In comparison with the definition of net earnings which applied prior to the reform, this means that actual PAYG pension levels will fall by a larger margin (by some 10 percent to about 63.5 percent) than suggested by the new definition.

\section{(3) Spread of supplementary private pension savings}

The decline in public pensions is expected to be offset by supplementary (occupational and private) pensions. In order to achieve this aim, supplementary pensions are subsidized, either by tax deferral and tax deduction, or by direct subsidies to individual and occupational pension plans. These supplementary pensions are, however, not mandated. 
Table 4 gives an overview over the main changes. Subsection 4.4 describes in detail how costs in the PAYG pillar are cut. The emerging gap is supposed to be filled by private individual and occupational pensions. Subsection 4.5 describes the subsidies for the private supplementary funded pensions. Subsection 4.6 describes the changes in occupational pension. An assessment of the likely economic success of the Riester reform follows in section 5.

Table 4: Overview of the core elements of the Riester-Reform

\begin{tabular}{lll}
\hline Measure & Content & Pillar \\
\hline $\begin{array}{l}\text { Introduction of a needs- } \\
\text { oriented basic income }\end{array}$ & $\begin{array}{l}\text { Minimum social security guarantee for old age; } \\
\text { reduction in earning capacity secured by means of } \\
\text { needs-oriented basic income }\end{array}$ & 0 \\
\hline New adjustment formula & Reduction in pension level by about 10 percent & 1 \\
\hline $\begin{array}{l}\text { Abolition of occupational } \\
\text { incapacity pensions }\end{array}$ & $\begin{array}{l}\text { Discontinuation of occupational incapacity pensions; } \\
\text { replacement by two-tier general invalidity pension }\end{array}$ & 1 \\
\hline $\begin{array}{l}\text { Reform of women's and } \\
\text { survivors' pensions }\end{array}$ & $\begin{array}{l}\text { Modification of income rules for survivors' pensions; } \\
\text { introduction of “pension splitting for married couples" }\end{array}$ \\
\hline $\begin{array}{l}\text { Reformed framework for } \\
\text { occupational pensions }\end{array}$ & $\begin{array}{l}\text { Introduction of a legal right to convert salary into } \\
\text { pension contributions; relaxation of investing rules; } \\
\text { introduction of pension funds; DC-plans permitted }\end{array}$ & 2 \\
\hline $\begin{array}{l}\text { Establishment of funded } \\
\text { (voluntary) supplementary } \\
\text { pension provision }\end{array}$ & $\begin{array}{l}\text { Introduction of individual retirement accounts; rules } \\
\text { for the recognition of financial services products } \\
\text { eligible for state subsidies (Retirement Pension } \\
\text { Contracts Certification Act); provision of state } \\
\text { subsidy; introduction of deferred taxation }\end{array}$ & 3 \\
\hline
\end{tabular}

Source: Authors compilation

\subsection{The PAYG pillar: reducing the replacement rate}

The calculation of the current monthly pension value $P V_{t}$ for a specific year $t$ takes account of the development of the earnings of all workers, see section 2.2. This procedure is intended to guarantee that the so called "standard pension replacement rate" remains stable and does not 
fall behind the development of current average earnings. ${ }^{29}$ Before the 2001 reform, the objective of safeguarding standards of living in old age was considered to be met if pensions were worth 70 percent of average net earnings. Thus they more than maintain the purchasing power of the level of pension entitlements acquired when a person retires. Until the 2001 reform, the German pension system was essentially run by adapting the contribution rate to this 70 percent standard replacement rate.

In 2001, the Riester Reform introduced a rather complex new adjustment formula, which relates changes in the pension value $\left(P V_{t}\right)$ to lagged changes in gross income $\left(A G I_{t}\right)$, modified by the actual contribution rate to public pensions $\left(\tau_{t}\right)$ and a fictitious contribution rate to the new private pension accounts $\left(A V A_{t}\right)$, gradually increasing from 0.5 percent in 2003 to 4 percent in 2009. In addition, a somewhat awkward ,sensitivity factor" $d_{t}$ was introduced. It is 100 until 2010, then decreases to 90 which effectively increases the sensitivity of $P V$ to increases in $\tau$ after 2010. It thus simply decreases the replacement rate after 2010.

$$
P V_{t}=P V_{t-1} \frac{A G I_{t-1}}{A G I_{t-2}} \frac{\frac{d_{t}}{100}-A V A_{t-1}-\tau_{t-1}}{\frac{d_{t}}{100}-A V A_{t-2}-\tau_{t-2}} .
$$

The complex design of the formula reflects the balance between the two opposing aims of the reform: to keep the contribution rate below a fixed level (20 percent until 2020, 22 percent until 2030), and to keep the redefined standard replacement level above 67 percent until 2030. Both conflicting aims are part of the German pension law. If any of these aims are violated, the law precipitates government action, such as the introduction of the reform commission in 2003. Note that the awkward jump in the sensitivity factor $d_{t}$ reflects the aims since the system dependency ratio is still flat until 2010 and then quickly rises, see Figure 1.

\footnotetext{
${ }^{29}$ The reader is reminded that the word replacement rate may be misleading: In the German context, it does NOT refer to last earnings before retirement. Rather, the "standard replacement rate" refers to the pension of a worker, who had 45 earnings points, divided by the average net earnings off all current workers.
} 


\subsection{The new funded pillar: introducing supplementary funded pensions}

A crucial component of the Riester reform is the introduction and significant promotion of supplementary funded private pensions to fill the pension gap created by the reduction of the replacement rate. The objective is to offer incentives for people to take out supplementary private pension cover which, in the long term, should compensate for the future cuts in public pensions. However, there will be no legal mandate for people to invest in additional private schemes. These Riester pensions can be occupational or individual pensions. Since many restrictions apply, it remains to be seen, how many workers actually start building up private pensions.

The main restriction is on payment plans. Since additional private pension schemes are intended to supplement or replace benefits from the public pension scheme, the government decided that incentives will only be available for investment vehicles which guarantee payment of a life annuity payable from the date of retirement. Investment vehicles which provide for lump-sum disbursements are not subject to state subsidies. ${ }^{30}$ This restriction has already met with considerable criticism in the public debate as it excludes other forms of provision for old age (such as investments in old-age or nursing homes).

The incentives provided by the state can take two forms: direct savings subsidies or taxdeductible special allowances. The tax authorities automatically compute which of the two forms versions is most advantageous.

Direct savings subsidy. All dependently employed and certain self employed workers who pay personal contributions to a certified retirement pension policy are entitled to receive a direct retirement savings subsidy. The subsidy is paid directly into the beneficiary's saving account. A basic subsidy and a child subsidy for each child for which child benefits were received during the previous year is paid. Child subsidies are payable to the mother. In the case of married couples, both partners receive a basic subsidy if they have each taken out their own supplementary private pension policy. In addition, non-entitled partners (such as mothers not in paid employment) are also entitled to receive the full subsidy for their own retirement pension policy provided that the respective married partner subject to compulsory insurance 
contributions has paid his or her minimum personal contribution to their supplementary retirement pension policy (see below).

Table 5: Direct savings subsidies

\begin{tabular}{cccc}
\hline From ... on & Savings rate & $\begin{array}{c}\text { Basic subsidy in } \\
\text { Euro/Year }\end{array}$ & $\begin{array}{c}\text { Child subsidy } \\
\text { in Euro/Year }\end{array}$ \\
\hline 2002 & 1 percent & 38 & 46 \\
2004 & 2 percent & 76 & 92 \\
2006 & 3 percent & 114 & 138 \\
2008 & 4 percent & 154 & 185 \\
\hline
\end{tabular}

Table 5 shows the maximum incentive subsidies available as of 2002. In order to qualify for the maximum subsidy the beneficiary must invest a specified percentage of his or her gross earnings (denoted as "saving rate"). This percentage increases until 2008 in four steps ("Riester-Treppe"). The percentage is applied to the actual earnings level, capped at the same cap as the PAYG contributions are (about 2 times average earnings). If less money is invested, the state subsidy is reduced accordingly. The scheme is complicated by the fact, that the subsidy is included in the savings amount. Hence, the actual saving rate necessary for the maximum subsidy is lower than the percentages indicated in the second column of Table 5. In turn, certain minimum amounts are necessary, see Table 6.

Table 6: Minimum Savings

\begin{tabular}{cccc}
\hline Year & No child & One child & Two or more children \\
\hline $2002-2004$ & 45 & 38 & 30 \\
As of 2005 & 90 & 75 & 60 \\
\hline
\end{tabular}

Tax deductible special expenses. Alternatively, qualifying retirement savings can be deducted as "special allowances" from income taxes. This is usually more advantageous for workers with higher than average earnings. Saving rates, caps etc. are the same as in the subsidy case. Table 7 shows the maximum tax-deductible contributions to private retirement savings accounts.

\footnotetext{
${ }^{30}$ If a lump-sum payment is chosen, all subsidies have to be reimbursed to the tax authorities.
} 
Table 7: Maximum Savings

\begin{tabular}{cc}
\hline From ... on & Tax deductible special expenses in Euro/Year \\
\hline 2002 & 525 \\
2004 & 1.050 \\
2006 & 1.575 \\
2008 & 2.100 \\
\hline
\end{tabular}

Criteria for individual pension plans eligible for subsidies/tax relief. Individual retirement accounts only qualify for state promotion if they meet criteria laid down in the new Certification of Retirement Pension Contracts Act (“AltZertG”). It contains a long list of rules which make the system complex for customers and potential insurers alike, see section 5 . Qualifying pension plans require certification by the Federal Financial Markets Authority ("Bundesanstalt für Finanzdienstleistungs- und Finanzmarktaufsicht") which will be granted automatically if they fulfill the following preconditions:

1. The investor must be committed to making regular, voluntary pension contributions.

2. Pension benefits may only be paid out when the beneficiary reaches the age of 60 at the earliest or upon reaching retirement age.

3. At the beginning of the disbursement phase, the accrued pension contributions (inclusive of subsidies) must be guaranteed (i.e., the nominal rate of return must be nonnegative).

4. Pension payments must guarantee lifelong benefits which retain or increase their nominal value, i.e. in the form of a life annuity or disbursement plan linked to lifelong annual installments.

5. The disbursement plan must continue to provide benefits until the beneficiary reaches the age of 85 and subsequently provide a life annuity guaranteed by the capital available at the beginning of the disbursement phase.

6. Supplementary survivor's coverage must not have features which offset the original plan.

7. Initial commission and administrative charges must be spread equally over a period of at least 10 years. 
8. The investor must be informed about the following issues before taking out the policy: The level and distribution over time of commission and administrative costs, the cost of switching to a different policy, the costs of financial management, the costs involved in changing to a different insurer.

9. The investor must be informed once a year during the term of the policy about how his or her contributions are being used, capital formation, costs and yields, and also about whether and to what extent the insurer takes account of ethical, social and ecological investment criteria.

10. The investor must have the right to suspend contributions during the saving phase, to allow the policy to continue running without making additional contributions, or to terminate the policy by serving three months notice to the end of the quarter.

11. Policy rights may not be assigned or transferred to third parties. Claims to pension benefits cannot, as a result, be bequeathed.

Products eligible for subsidy support and into which old-age pension contributions and the proceeds on such contributions may be invested include pension insurance and capitalization products, bank accounts with accumulated interest and shares in growth and distributing investment funds. These products are offered by life insurance companies, banks, capital investment companies, financial services institutions and securities services companies.

Deferred taxation. While old-age pension contributions will be tax exempt during the saving phase, pension payments during the benefit phase will be taxed in full as normal income. This applies to all benefits regardless of whether these accrue from contributions, subsidies or capital gains. One may regard this as another form of subsidy, since taxes occur later in life (hence, an implicit tax credit) and usually at a lower rate due to progressivity. ${ }^{31}$

\footnotetext{
${ }^{31}$ Börsch-Supan and Lührmann (2000). The "tax credit" feature depends on the an income or consumption tax point of view.
} 


\subsection{State promotion of occupational pension schemes}

The Riester reform remained largely undecided on the role of occupational pensions versus individual accounts. Traditionally, occupational pensions have played a minor role in Germany, particularly in comparison with other countries. Demand for participation in occupational pension schemes has also been falling in recent years. ${ }^{32}$ On the other hand, occupational pensions may provide a psychological substitute for mandated private pensions. In order to strengthen occupational pensions, additional (implicit and explicit) subsidies were introduced with the Riester reform.

The most important change is the general right to convert part of the salary directly into contributions to pension plans. This applies regardless of whether the contributions are paid by the employer or the employee. Arrangements may be based both on gross or net pay. If they are based on net pay, there is a large implicit subsidy since the so-converted salary may not only be subject to deferred taxation but can also be exempt from social security contributions, at least until 2008. If they are based on gross pay, contributions may enjoy the same direct subsidies or tax relief as contributions to individual accounts, as long as the occupational pensions meet certain criteria which are less restrictive than the criteria for individual pension plans. Which contribution rules apply depends on the chosen investment vehicle and the incentives they attract. (See below and Table 8) Collective bargaining agreements, however, have precedence over the right to convert salary. This means that an employee covered by a binding collective agreement is only entitled to convert his or her pay into pension if this is explicitly provided for in the terms of the collective agreement. This rule makes sure that employers and unions can impose their own rules on occupational pension plans.

Investment vehicles and eligibility for Riester subsidies/tax relief. The Riester reform also introduced pension funds as a vehicle for occupational pensions - an investment vehicle which is widely used in other countries, but was not permitted in Germany. There are now five different investment vehicles in German occupational pension schemes (see Table 8 for an overview of their features). Only three of them are eligible for Riester incentives: (1) direct insurance, (2) staff pension insurance and (3) pension funds. As the employer has to provide

\footnotetext{
${ }^{32}$ See Ruppert (2000).
} 
the employee with the possibility to benefit from the Riester incentives, this means - especially for smaller companies - that some companies now have to restructure their pension schemes.

Table 8: Types of occupational pension systems

\begin{tabular}{|c|c|c|c|c|c|}
\hline \multirow[t]{2}{*}{ Features } & \multicolumn{5}{|c|}{ Investment Vehicles } \\
\hline & $\begin{array}{l}\text { Direct } \\
\text { pension } \\
\text { promise } \\
\text { (Direkt- } \\
\text { zusage) }\end{array}$ & $\begin{array}{c}\text { Benefit } \\
\text { funds } \\
\text { (Unter- } \\
\text { stützungs- } \\
\text { kasse) }\end{array}$ & $\begin{array}{c}\text { Direct } \\
\text { insurance } \\
\text { (Direkt- } \\
\text { versicherung) }\end{array}$ & $\begin{array}{l}\text { Staff pension } \\
\text { insurance } \\
\text { (Pensions- } \\
\text { kasse) }\end{array}$ & $\begin{array}{l}\text { Pension funds } \\
\text { (Pensions- } \\
\text { fonds) }\end{array}$ \\
\hline $\begin{array}{l}\text { Tax on } \\
\text { contribution } \\
\mathrm{S}\end{array}$ & \multicolumn{2}{|c|}{ Tax free } & $\begin{array}{l}\text { 1. Flat-rate tax } \\
\text { 2. Fully taxed } \\
\text { but Riester } \\
\text { subsidy/ tax } \\
\text { deductable } \\
\text { expense }\end{array}$ & $\begin{array}{l}\text { 1. Flat-rate tax } \\
\text { 2. Fully taxed } \\
\text { but Riester } \\
\text { subsidy/ tax } \\
\text { deductable } \\
\text { expense } \\
\text { 3. Tax free } \\
\text { until } 4 \% \text { of } \\
\text { BMG }\end{array}$ & $\begin{array}{l}\text { 1. Fully taxed } \\
\text { but Riester } \\
\text { subsidy/tax } \\
\text { deductable } \\
\text { expense } \\
\text { 2. Tax free } \\
\text { until } 4 \% \text { of } \\
\text { BMG }\end{array}$ \\
\hline $\begin{array}{l}\text { Tax on } \\
\text { benefits }\end{array}$ & \multicolumn{2}{|c|}{ Fully taxed } & $\begin{array}{l}\text { 1. Tax on } \\
\text { returns only } \\
\text { 2. Fully taxed }\end{array}$ & $\begin{array}{l}\text { 1. Tax on } \\
\text { returns only } \\
\text { 2. Fully taxed } \\
\text { 3. Fully taxed }\end{array}$ & $\begin{array}{l}\text { 1. Fully taxed } \\
\text { 2. Fully taxed }\end{array}$ \\
\hline Investment & \multicolumn{2}{|c|}{ Internal } & \multicolumn{3}{|c|}{ external } \\
\hline $\begin{array}{l}\text { Investment } \\
\text { rules }\end{array}$ & \multicolumn{2}{|c|}{ None } & \multicolumn{2}{|c|}{$\begin{array}{c}\text { Acc. Insurance Supervisory } \\
\text { Act }\end{array}$} & None \\
\hline $\begin{array}{l}\text { Insolvency } \\
\text { scheme }\end{array}$ & \multicolumn{2}{|c|}{$\begin{array}{l}\text { Membership in pension } \\
\text { insurance fund (PSV) }\end{array}$} & \multicolumn{2}{|c|}{ No } & $\begin{array}{l}\text { Membership } \\
\text { in PSV }\end{array}$ \\
\hline $\begin{array}{l}\text { State } \\
\text { supervision }\end{array}$ & \multicolumn{2}{|c|}{ No } & \multicolumn{3}{|c|}{$\begin{array}{c}\text { Federal Insurance Authority } \\
\text { (Bundesaufsichtsamt für das } \\
\text { Versicherungswesen). }\end{array}$} \\
\hline
\end{tabular}

Note: $\mathrm{BMG}=$ earnings threshold (Beitragsbemessungsgrenze, see section 2.1).

Source: Author's compilation 


\section{An Assessment of the Riester Reform}

Will the recent reforms, and in particular the Riester reform, solve the problems of the German public pension system? An important and still open question is whether the new voluntary supplementary private pensions, the so-called Riester pensions, will be accepted by the German workers who were used to the all-caring public system. This is topic of subsection 5.1. Subsection 5.2 then asks, whether the new supplementary private pensions will suffice to offset the cuts in the PAYG pillar if workers actually participate. Finally, subsection 5.3 combines these results and poses the main question: Will the Riester reform put the German system of old age provision on a stable and lasting new foundation?

\subsection{Will the "Riester" pensions actually take off?}

Since the new pensions are voluntary, one of the most debated issues in the context of the Riester reform is the question whether workers will actually overcome the temptations to procrastinate. How many will build up supplementary pensions? How much will they save? At this point, only one year since their introduction, it is too early to tell. It took about 5 years to popularize a general subsidized dedicated savings program ("Vermögenswirksame Leistungen", directly deducted from payroll) which now enjoys almost universal participation. In the US, IRAs needed at least as long to be accepted by a large share of households. In this section, we look at the design and the incentives in order to understand who is likely to take up the private Riester pensions.

The depth of Riester incentives. Two aspects need to be taken into account when assessing the benefits offered by Riester incentives: the subsidies/tax exemptions during the contribution phase and any tax-related advantages or disadvantages which arise during the disbursement phase. The direct subsidies during the contribution phase are very deep for those who have relatively low income and those who have children. The reverse is the case for the taxdeductible special allowances, due to the progressive tax system. Here, households with higher incomes benefit more. This results in a U-shaped relation between subsidies and income, 
visible in Figure 6 which shows the subsidy as a percentage of savings in form of the new supplementary pensions. ${ }^{33}$

\section{Figure 6: Depth of subsidies to Riester pensions}

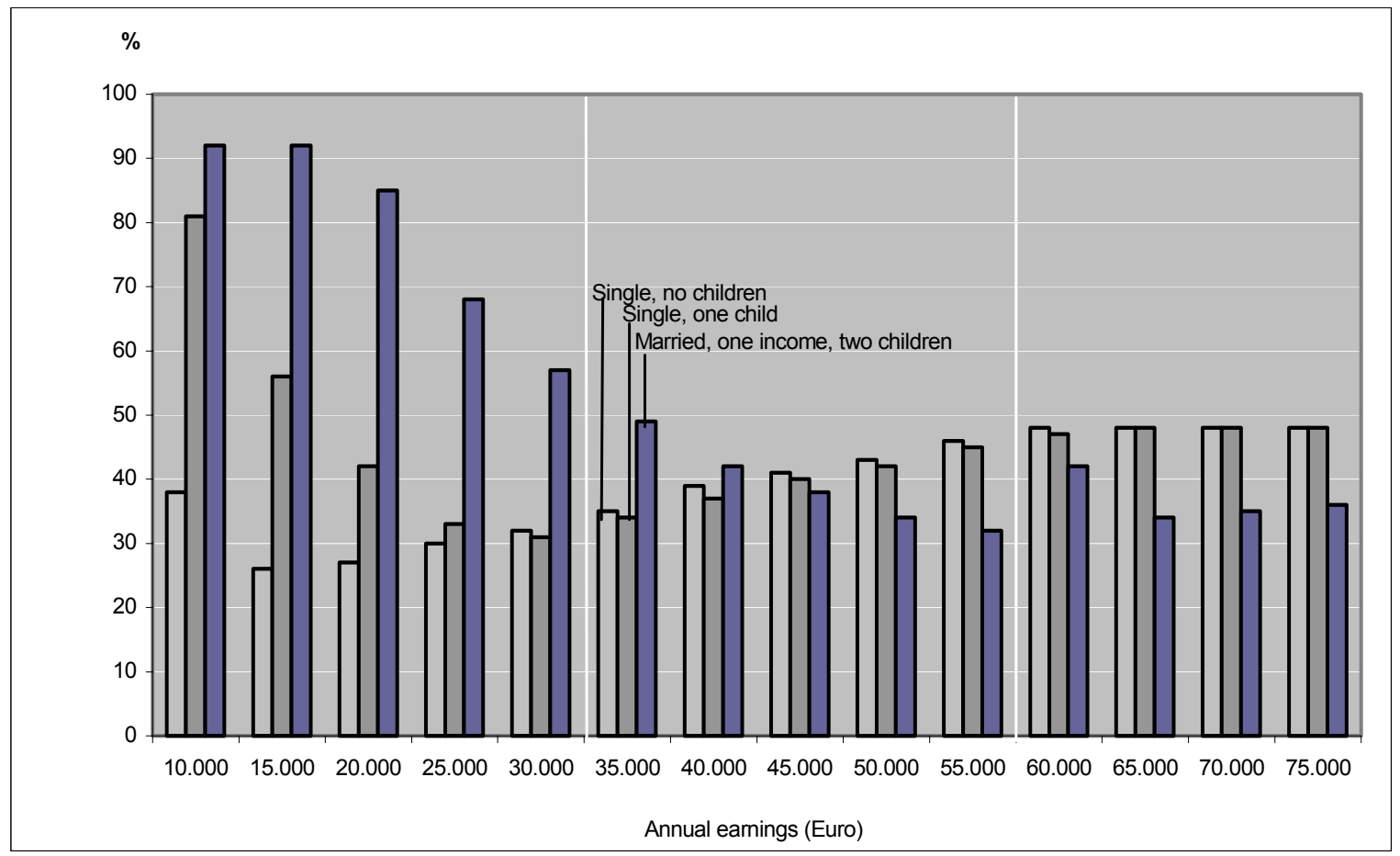

Note: Direct subsidy/the tax advantage as a percentage of savings in form of the new supplementary pensions. Source: Deutsche Bundesbank (2002).

For lowest income households, the subsidy is almost as large as the contribution itself. Even for the well-to-do, subsidy rates are high around 40-50 percent. Given these deep subsidies, uptake is likely to be high.

The picture of Figure 6, however, is misleading insofar as this U-shaped curve is flattened out during the disbursement phase when pension benefits will be taxed. This flattening effect is due to the impact of progressive taxation. Taxation will not affect pensioners in the lower half of the income distribution because their pension income is below a generous exemption for retired households. It will, however, considerably reduce the effective lifetime subsidy to households with incomes above average.

\footnotetext{
${ }^{33}$ We use the word "subsidy" for both the direct subsidy and the tax-deductible special allowance.
} 
The form of the Riester incentives. While the depth of the Riester incentives makes the Riester pensions rather attractive, the Riester pension is less flexible than other retirement investment products.

One of the main complaints is that most of the capital has to be annuitized and can therefore not be used as collateral or bequeathed. The argument lacks a certain logic since the very objective of the Riester pensions is to provide annuity income in order to fill the pension gap emerging from the reduced PAYG pillar. In our opinion, the widely voiced argument is a clear indication that most workers have not yet realized that they will depend on the Riester pensions for a reasonable retirement income.

The extensive certification requirements which severely restrict private providers' scope to develop new private insurance products and which lead to higher costs is also disadvantageous. Certain cost items can result in total costs of up to 20 percent, compared with around 10 percent for a normal capital sum life insurance policy. ${ }^{34}$

What is more, the certification rules merely serve to create a formal product standard without creating the transparency needed in order to compare different investment vehicles and the relative rates of return they offer. As a result, customers are often not in a position to make truly informed private investment decisions. The guarantee of the nominal value of contributions does ensure that, on retirement, at the very least the nominal capital saved is available as pension capital. However, there are no rules which prescribe the sort of pension dynamisation which is needed in order to ensure that the value of pension benefits paid out from the saved capital can be maintained over the long term. Non-dynamised Riester benefits will very quickly lose their value, even at very modest rates of inflation.

Preliminary evidence on take-up rates. First survey results show that demand for Riester products is sluggish: only around 9 percent had actually taken out a policy by mid 2002; a further 16 percent planned to conclude a policy by the end of 2002. By early summer 2003, however, the take-up rate has increased to about 35 of all eligible workers.

This comes during a growing trend for workers to enroll in supplementary pension plans. Only around half of those planning to enroll in such plans are considering doing so in the framework

\footnotetext{
${ }^{34}$ Stiftung Warentest (2002).
} 
of a Riester policy. The other half prefer other savings and insurance products, and/or occupational pensions. ${ }^{35}$

Moreover, many households, especially in the higher income brackets, merely may restructure their existing pension plans in order to reap Riester subsidies. At this point, we do not have much hard evidence on such substitution. Should these households have a fixed pension target, financing state subsidies via general taxation can actually have perverse effects which lead to a lower savings rate. ${ }^{36}$

Mandatory private pensions? Surveys have shown that a large section of the population would actually welcome the introduction of mandatory supplementary private pensions. ${ }^{37}$ This preference may be explained by savers' lack of confidence in their ability to exercise the discipline needed to build up additional old-age provision by themselves and the fiscal externality imposed by those who speculate on general social assistance rather than save.

The argument generally cited in favor of mandatory supplementary old-age provision are poverty in old age and adverse selection on the insurance market. ${ }^{38}$ Poverty in old age, however, is currently not an important problem in Germany. This may change in the future because of the benefit cuts, but has been addressed by the Riester reform through the introduction of the new minimum income guarantee.

As far as adverse selection is concerned, compulsory provision could lead to a monopoly position being established by a single provider if this product and the offers it generates proves to be unattractive for smaller competitors in which case coercion would bring about even less rather than more product variety.

Finally, making supplementary pensions mandatory will give the savings a tax-like character and may therefore create negative incentive effects. ${ }^{39}$ The very idea of reducing the tax and

\footnotetext{
${ }^{35}$ Leinert (2002).

${ }^{36}$ See Börsch-Supan and Lührmann (2000).

${ }^{37}$ Boeri, Börsch-Supan and Tabellini (2001, 2002a, b).

${ }^{38}$ Börsch-Supan (2002b).

${ }^{39}$ Summers (1989).
} 
payroll-tax-like contribution burden in order to stimulate economic growth would then be jeopardized.

\subsection{Will the "Riester" pensions fill the pension gap?}

Main point of introducing the Riester pensions was to compensate for the reductions in the pay-as-you-go public retirement insurance scheme. Model calculations show that an envisaged savings rate of 4 percent of gross income is in principle sufficient to close the gap which will open up in old age provision as a result of the cuts in state pensions. Figure 7 illustrates the growing pension gap (defined as the difference between today's and forecasted future gross pension levels) and the level of additional benefits provided by the Riester pension based on different assumptions regarding rates of return.

\section{Figure 7: Filling the pension gap}

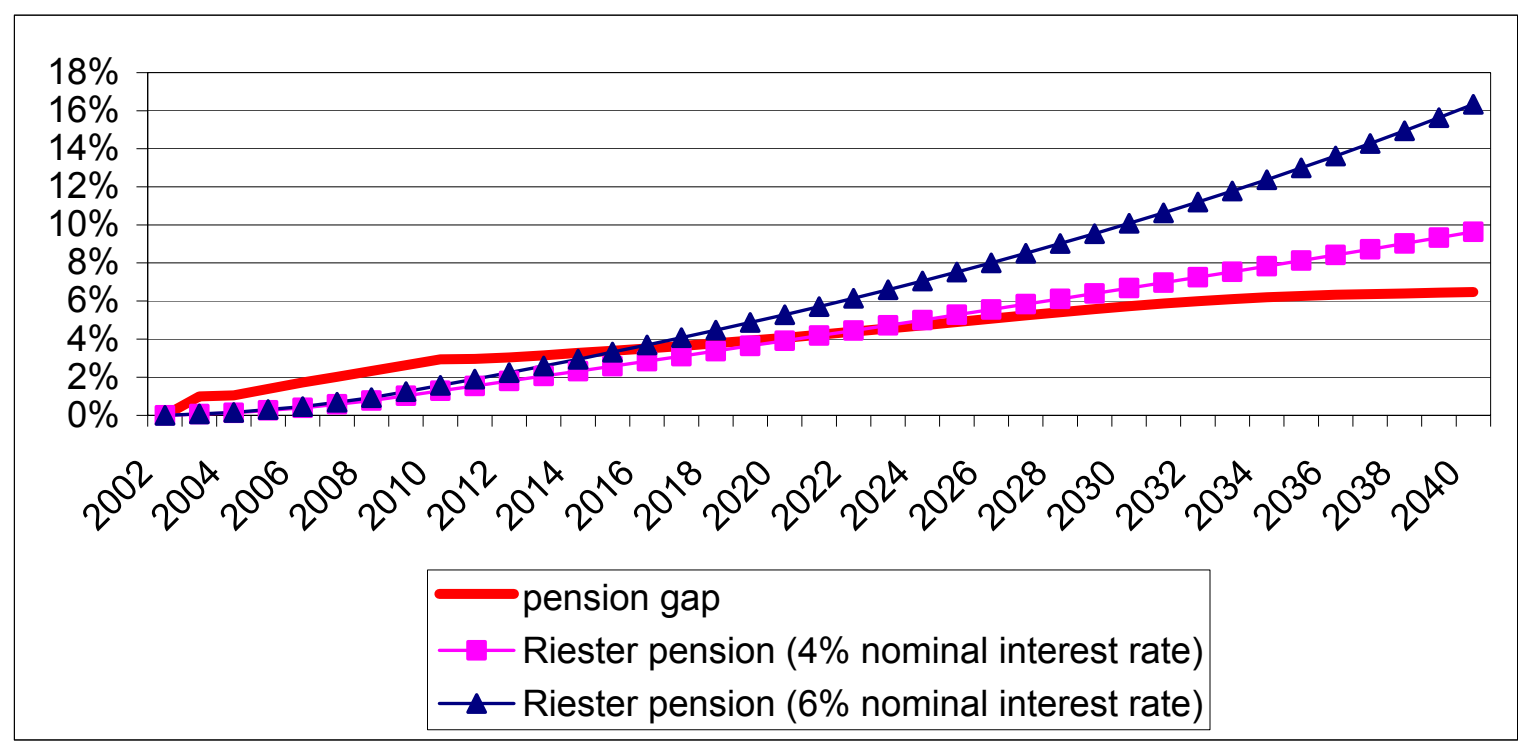

Source: MEA calculations based on the Rürup commission's demography and labor market projections.

While the Riester pensions can fill the pension gap in the long run, they are however, not sufficient for the older cohorts. Younger cohorts born after 1970 will be in a position to build up even higher pension entitlements than was previously the case, thanks to their supplementary pension savings. Older cohorts, however, will need to save more than the envisaged maximum saving rates in Table 5 in order to close this gap entirely during the time 
still available to them. Obviously, rather than a slow increase to a fixed 4 percent of gross income, initial saving rates have to be high and be tailored to each cohort. ${ }^{40}$

Given successful take-up, the future composition of retirement income will be quite different from the current monolithic one. Figure 8 outlines this development by birth cohort in the year of their retirement under the assumption that the insured cohorts have adhered to the recommended Riester savings rates of Table 5.

Figure 8: Composition of retirement income by birth cohort

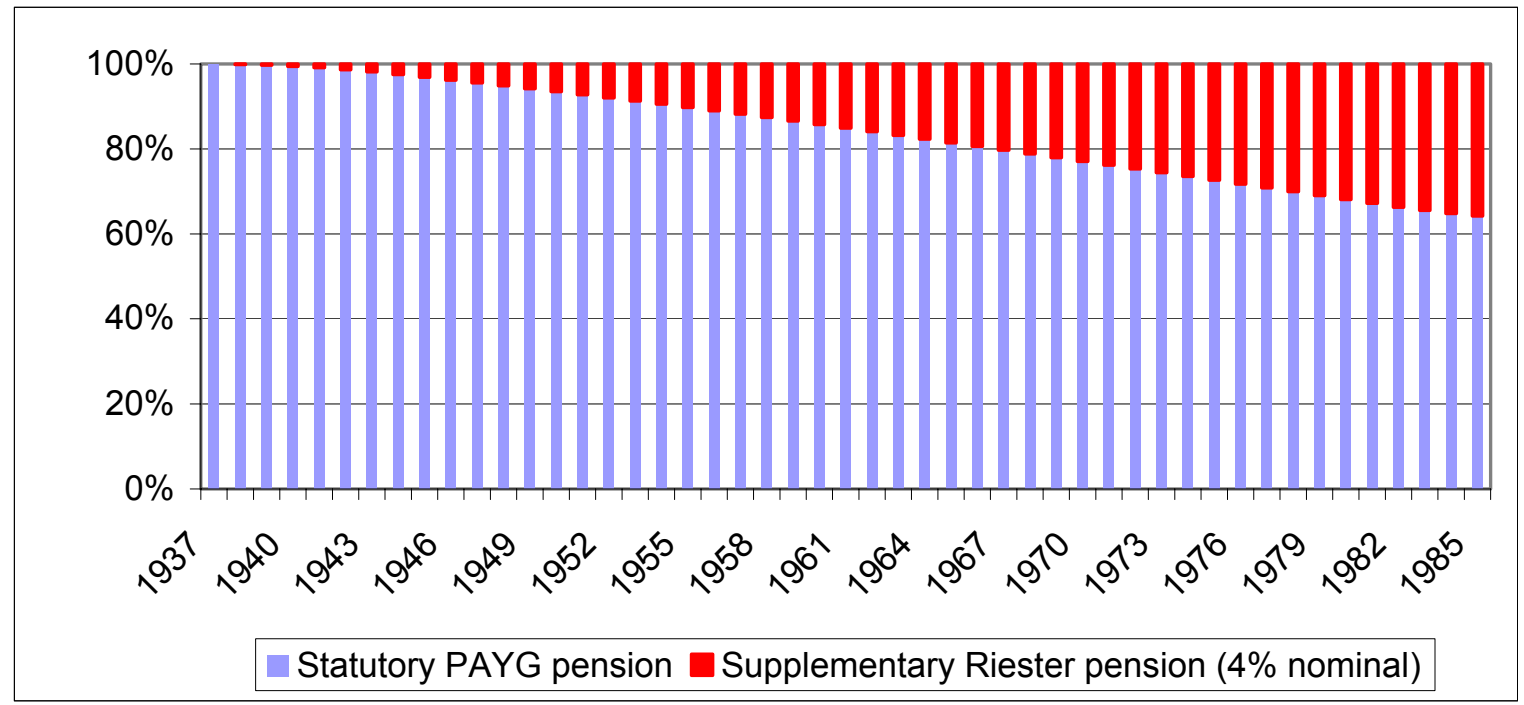

Source: MEA calculations based on the Rürup commission's demography and labor market projections.

Figure 8 shows that even at full uptake, the German PAYG system will remain the dominant pillar for old age provision. Riester pensions will make up about 35 percent of state organized retirement income. Should other income sources (currently about 15 percent of total retirement income) stay as they are, this would yield a share of PAYG pensions in total retirement income at about 55 to 60 percent. Some crowding out of existing occupational pensions and other private pensions by the new Riester pensions is likely, however, as mentioned earlier.

\footnotetext{
${ }^{40}$ See the proposals by Birg and Börsch-Supan (1999) and Börsch-Supan (2002).
} 


\subsection{Will the "Riester" reform stabilize the German pension system?}

Of course, the main litmus test of the Riester reform is whether the shift from PAYG to a partially funded pension system will stabilize the contribution rates for the younger generation with acceptable replacement rates for the older generation. The Riester reform actually was quite courageous in writing into the law that the standard pension replacement level must not fall below 67 percent and at the same time that the contribution rate must not exceed 20 percent until 2020 and 22 percent until 2030. Can these promises be kept?

The answer is - quite unambiguously - no. Our answer is based on the "official" demography and economic projections adopted by the "Rürup commission" and the Ministry for Health \& Social Security. ${ }^{41}$ We look first at standard replacement rates. ${ }^{42}$ Model calculations of the long-term impact of pension adjustments demonstrate that, as a result of the new Riester adjustment formula, future pension levels will fall more than first predicted by the government, see Figure $9{ }^{43}$ They will fall below 67 percent very quickly, and eventually reach 62 percent.

Figure 9: Development of pension levels prior to and after the 2001 reform

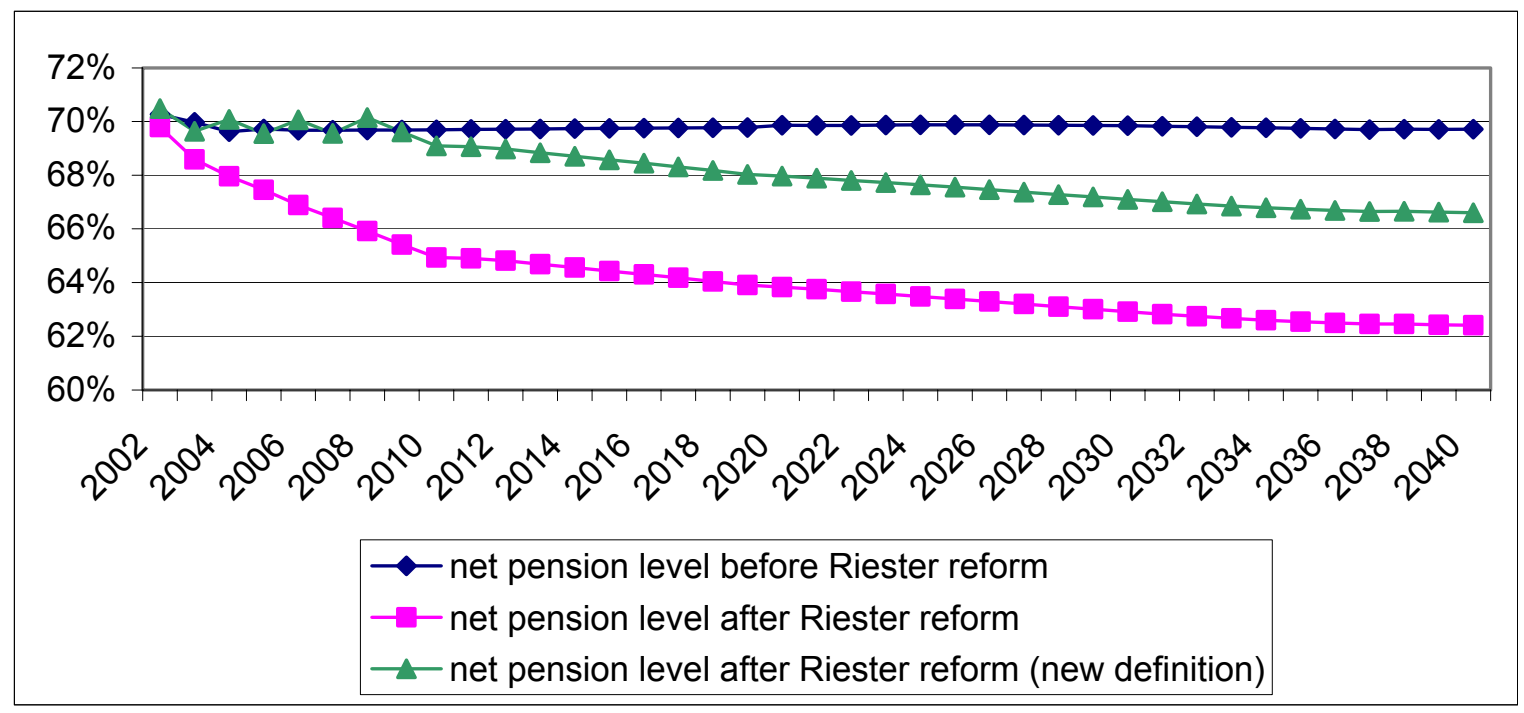

Source: MEA calculations based on the Rürup commission's demography and labor market projections.

\footnotetext{
${ }^{41}$ The demographic projections (fertility, mortality, migration) are considered realistic by academic demographers while the economic assumptions (growth, employment) are slightly optimistic.

42 The reader is reminded that the standard replacement rate does NOT relate to the LAST earnings before retirement. Rather, the "standard replacement rate" refers to the pension of a worker, who had 45 earnings points, divided by the average net earnings off all current workers.

${ }^{43}$ See also Bonin (2001) and Prognos (2001).
} 
The scale of this reduction also clearly demonstrates that the pension benefits provided by the PAYG public retirement insurance scheme will not be sufficient in themselves - that is without supplementary pension provision - to safeguard pensioners' standards of living in old age.

Although the new adjustment formula will in effect bring about a larger reduction in pension levels than was perceived by public opinion, the most dramatic difference between promise and current projection relates to the objective of stabilizing contribution rates. Figure 10 depicts our projection for the long-term development of contribution rates prior to and after the reform.

Figure 10: Contribution rates prior to and after the 2001 Reform

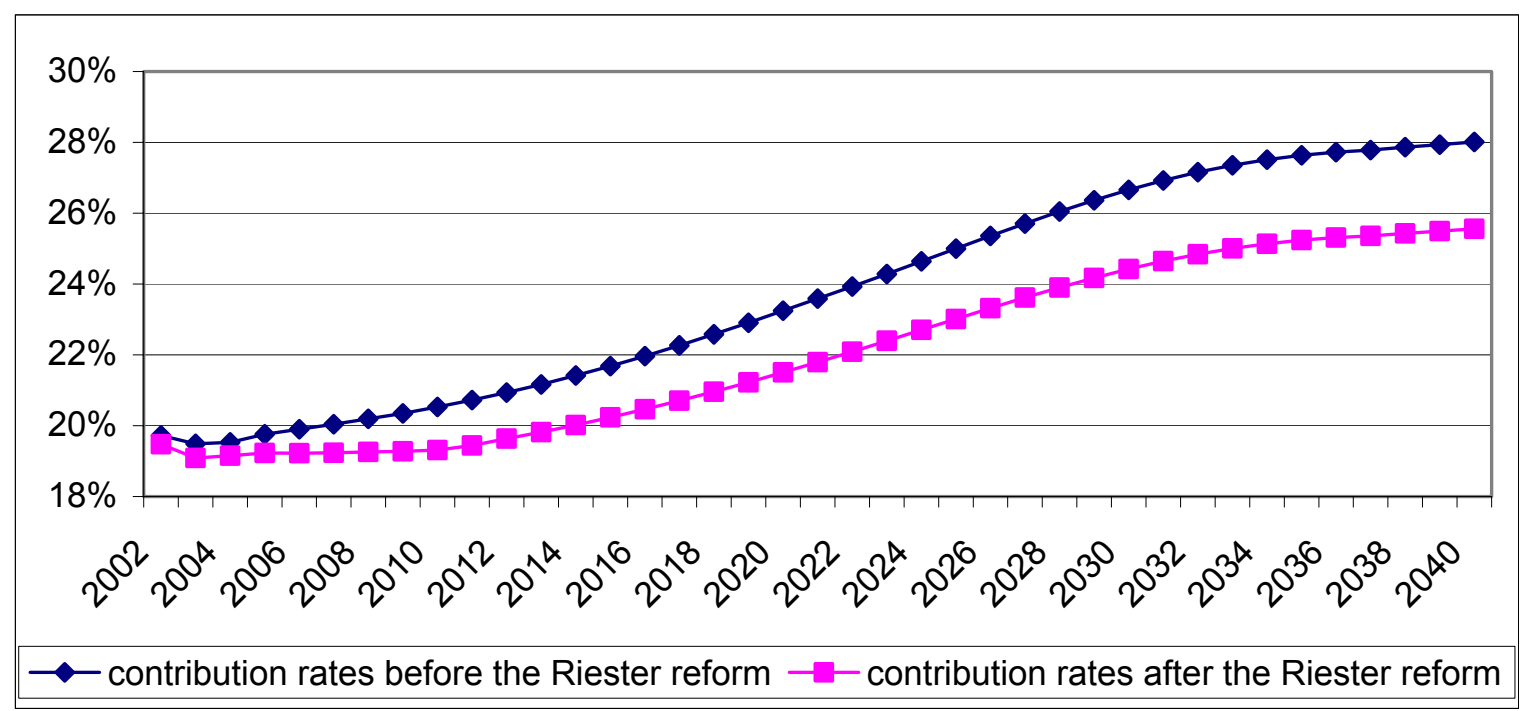

Source: MEA calculations based on the Rürup commission's demography and labor market projections.

While the Riester reform substantively reduces the contribution rate to the PAYG pillar, Figure 10 shows that the 20 percent line will be exceeded by 2014, and 22 percent by 2022 .

The apparent failure of the Riester reform to reach its main objectives - stabilization of the contribution rate at acceptable pension benefit levels - was not accidental. As a matter of fact, the overoptimistic demographic and economic assumptions were chosen in a fragile political compromise between reformists and unions that enabled the Riester reform package to pass the parliamentary hurdles. 


\section{New Efforts: The 2003 Proposals}

When it became obvious that the Riester reform measures would not suffice to meet the contribution rate and pension level targets, a new reform commission, the "Commission for Sustainability in Financing the German Social Insurance Systems", popularly referred to as the Rürup Commission after its chairman, Bert Rürup, was established in November $2002 .^{44}$ Its twin objectives are those of the Riester reform: to stabilize contribution rates while at the same time ensuring appropriate future pension levels.

The Rürup commission met in 2003 a very different situation than Riester in 2001. Unexpectedly high unemployment rates and the poor performance of the German economy with extremely low growth rates precipitated a short-run financial crisis of the pension system and created a sense of urgency for reform. Moreover, the electorate became increasingly aware that stabilizing social security contributions in total labor compensation is essential to enhance future growth. This paradigm shift away from thinking in pension claims towards thinking in financing possibilities had a noticeable impact on the commission's reform proposals.

In addition, the commission profited from the fact that the Riester reform had already paved the way for a more forceful shift from pay-as-you-go financed first-pillar pensions to funded second and third-pillar pensions.

\subsection{Reform proposals}

The reform proposal, published end of August 2003, comprises two major elements plus several accompanying measures. The first main element is a gradual increase of the normal retirement age from 65 to 67 years, the second a modification of the pension benefit indexation formula linking benefits to the system dependency ratio. The first element is accompanied by adjustments to the various early retirement ages, and the second element is accompanied by a revision of the Riester pension regulations. While the main two elements directly serve to achieve the desired stabilization of contribution rates, the accompanying measures keep the

\footnotetext{
${ }^{44}$ The commission was in charge of making reform proposals for the pension system, the health care and the longterm care insurance. We only refer to the pension proposals.
} 
system of pathways to retirement balanced and address some of the widely criticized aspects of the newly introduced second and third-pillar pensions.

Increase of the normal retirement age. The commission proposes to increase the normal retirement age from 65 to 67 years. The increase is slow and gradual, starting in 2011 with monthly steps such that age 67 will be reached in 2035. This increase corresponds to two-thirds of the projected change in life expectancy at age 65. It will therefore simply offset future increases in the total value of accumulated benefits generated by a longer pension recipiency duration. The reasoning behind this increase in retirement age is that the prolonged life span necessitates a commensurable increase in the active part of it, unless the pension system is continuously being expanded.

In order to prevent substitution into early retirement and disability pensions as a result of the increase in the retirement age, the commission also proposed to increase the early retirement ages (at the same extent and schedule as the normal retirement age) and to increase the actuarial adjustments for disabled and long-term insured workers. Since there were additional worries about the coverage for workers subject to extreme physical wear and tear due to long years of hard work, a new pension type was introduced which makes it possible for workers with a service life of at least 45 years to retire two years earlier, however, with additional actuarial adjustments.

Change of the benefit indexation formula: the "sustainability factor". The commission proposes to extend the Riester benefit indexation formula by a new factor, the so-called "sustainability factor". This factor reflects the development of the relative number of contributors to pensioners, the system dependency ratio, which is the most important long-term determinant of pension financing. ${ }^{45}$ The new pension formula looks as follows:

\footnotetext{
45 Strictly speaking, the sustainability factor will link benefits to the "equivalized system dependency ratio" in order to avoid distortions created by extremely low contributions and/or pension benefits. This ratio standardizes the number of pensioners by converting standard pensions into the number of "equivalence pensioners". The number of "equivalence contributors" is likewise calculated by standardizing the average earner.
} 


$$
P V_{t}=P V_{t-1} \frac{A G I_{t-2}}{A G I_{t-3}} \frac{1-\delta_{t-2}-\tau_{t-2}}{1-\delta_{t-3}-\tau_{t-3}}\left(\left(1-\frac{P Q_{t-2}}{P Q_{t-3}}\right) \alpha+1\right)
$$

where PQ $=$ [pensioners / (contributors + unemployed) $]$

Note: The lags are due to data availability.

It includes the sustainability factor in the inner brackets, weighted by $\alpha$, and replaces the onetime shift in the somewhat awkward "sensitivity parameter" $d_{t}$, see section 4.4. If $\alpha$ equals zero, the current Riester pension adjustment formula would remain unchanged. If $\alpha$ equals one, the new indexation formula would imply a purely income-oriented pension benefit adjustment policy. The commission set the value of $\alpha$ at $1 / 4$, thereby fulfilling the Riester objectives to keep the contribution rate under 20 percent until 2020 and under 22 percent until 2030.

The new pension formula will lead to further decreases in pension benefit levels vis-à-vis the path planned by the Riester reform, see section 6.2. In contrast to the proposed "demography factor" in the failed 1999 reform attempt, the sustainability factor considers not only the development of life expectancy but the entire demographic development (including changes in migration and notably in birth rates), as well as the development on the labor market. This is important as the inevitably reduction of the working-age population can be compensated by a higher labor force participation of women and elderly workers. The introduction of the sustainability factor thus allows to directly link pension adjustments to the crucial factors determining pension financing, namely the number of contributors and benefit recipients. This gives the new pension benefit indexation formula a self-stabilizing effect.

Higher second and third-pillar pensions would compensate for this decrease. Since the uptake of the funded supplementary Riester pension has been modest so far (as was mentioned in section 5.1), the commission proposed a host of administrative changes to occupational and private pensions in order to make the system easier to handle and thus more popular. Among these are the expansion of the group of entitled persons to all tax payers, dynamic pension benefits, increased transparency in the private pension provision. These administrative changes accompany the proposed introduction of an EET-type ex post taxation of pensions. ${ }^{46}$

\footnotetext{
46 A parallel commission, also headed by Bert Rürup, proposed to keep pension contributions and capital gains tax exempt (symbolized by "EE"), and to tax benefits (symbolized by "T"). See Börsch-Supan and Lührmann (2000).
} 


\subsection{Long-term effects of the 2003 Reform proposals}

Are the reform proposals by the Rürup commission sufficient to counteract the foreseen consequences of demographic change and stabilize the system? Will it keep the contribution rate below the targets set by Riester, and at the same time generate a level of pension income that, taking all pillars into account, corresponds to today's level? This subsection presents a projection of the main components of the reform proposals and takes a look at their long-term effects. ${ }^{47}$ Figure 11 and Figure 12 illustrate how the introduction of the sustainability factor and the increase of the retirement age affect contribution rates and pension levels for varying values of $\alpha$.

Figure 11: The effects of the sustainability factor on the development of contribution rates

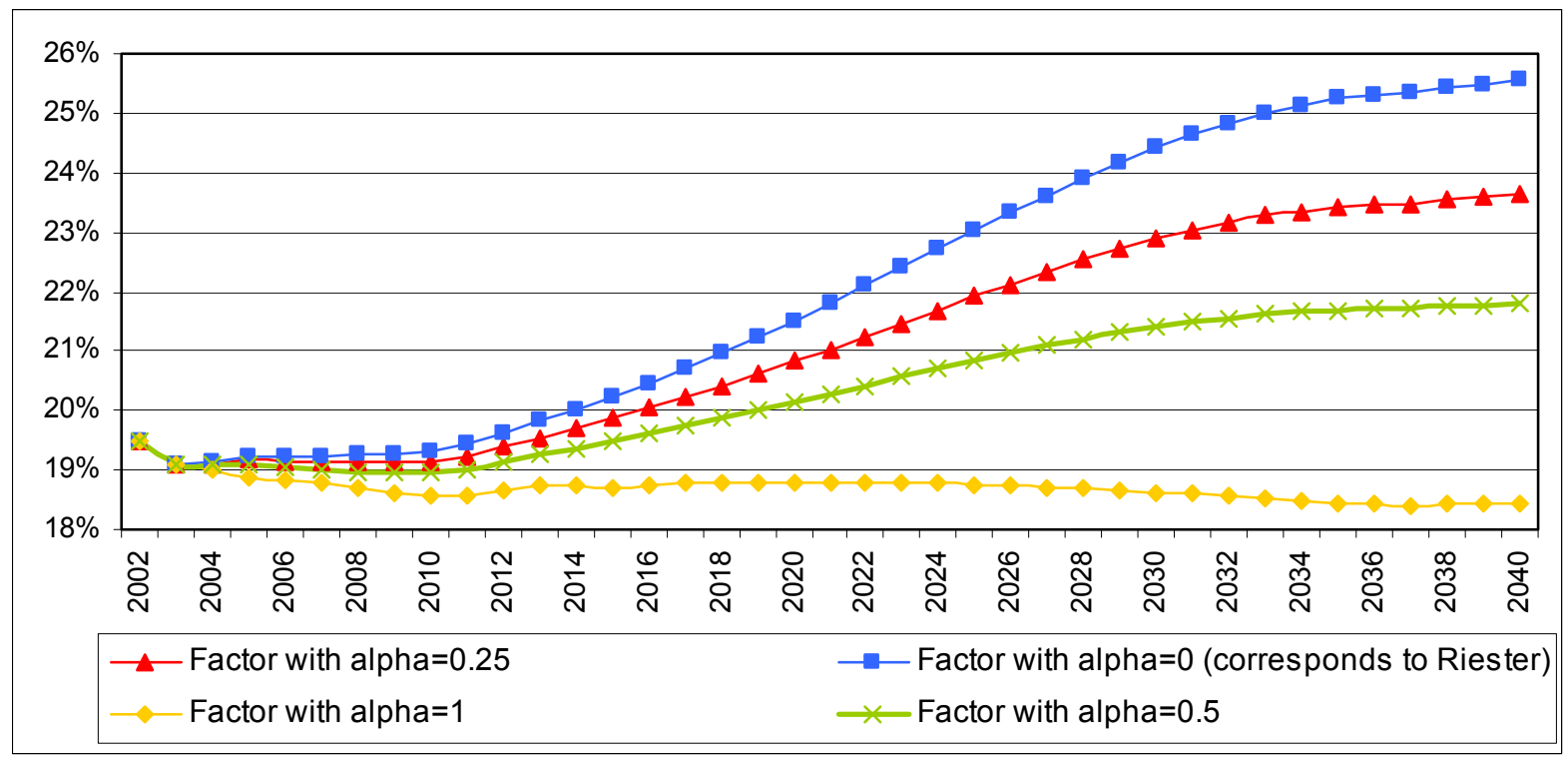

Source: MEA calculations based on the Rürup commission's demographic and labor market projections.

\footnotetext{
47 The official projections of the reform commission are presented in Kommission für die Nachhaltigkeit in der Finanzierung der Sozialen Sicherungssysteme (2003): Abschlußbericht. Bundesministerium für Gesundheit und Soziale Sicherheit, Berlin. (http://www.bmgs.bund.de/deu/gra/themen/sicherheit/kommission/index.cfm). (2003c).
} 


\section{Figure 12: The effects of the sustainability factor on pension levels}

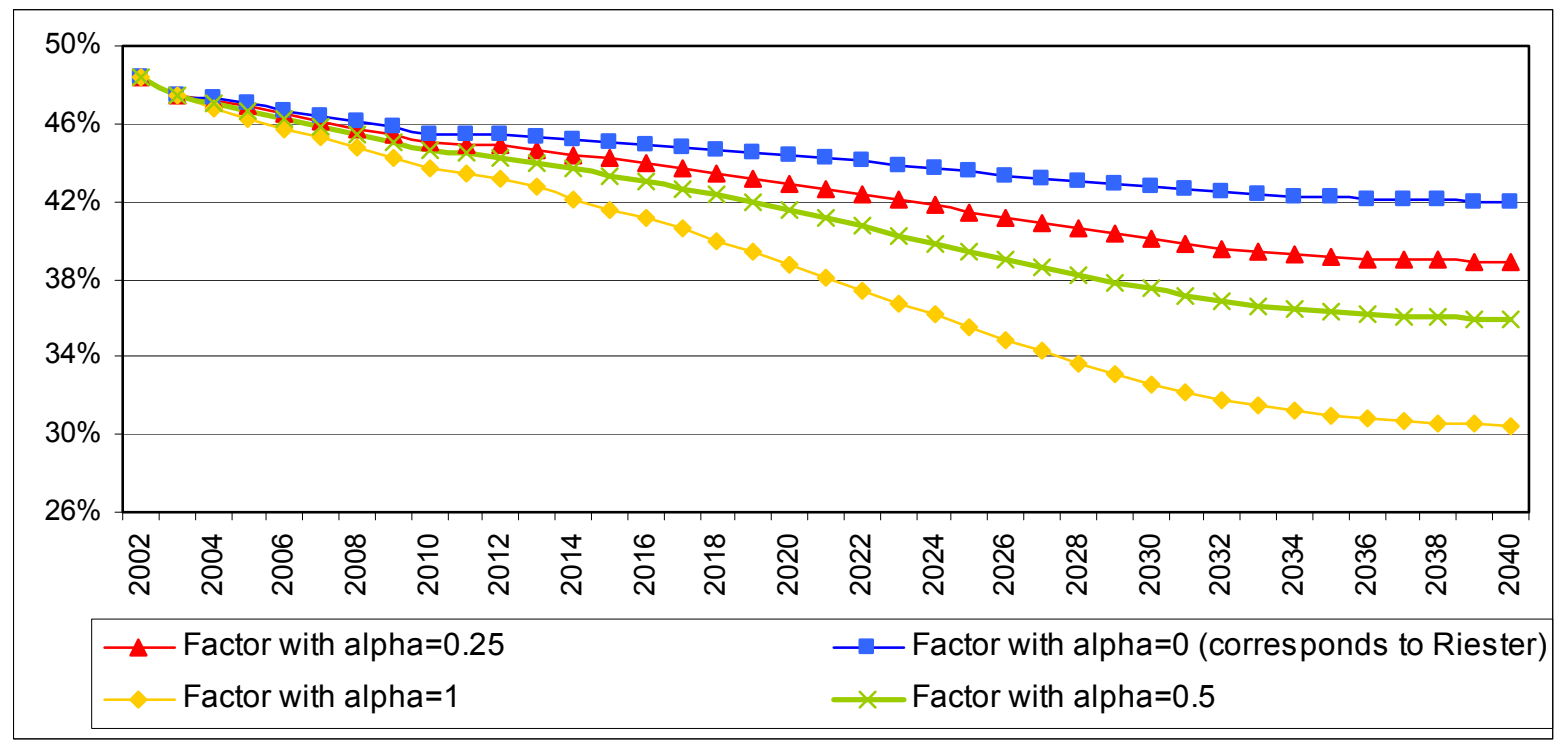

Source: MEA calculations based on the Rürup commission's demographic and labor market projections.

If $\alpha$ equals one, the sustainability factor generates a purely income-oriented pension benefit policy. The contribution rate will remain stable, while benefits will decline to around 30 percent of gross earnings.

A weighting factor $\alpha$ of 0.5 would spread the additional financial burden created by the increasing dependency burden more equally between contributors and beneficiaries. It results in a contribution rate of 20.1 percent in 2020, 21.4 percent in 2030, and a benefit level in 2030 of around 37 percent of gross earnings.

The commission's reform targets are just met when $\alpha$ is set equal to 0.25 . It results in a contribution rate a little lower than 23 percent in 2030, while the level of pensions is just over 40 percent of gross earnings.

Taking account of the increase in the normal retirement age to 67, which increases pension benefits according to the German benefit formula, and adding second and/or third pillar pensions, the Rürup proposal manages to deliver an income level for retirees that is comparable to today's income level - however, only after about 2030, see Figure 13. This projection assumes a saving rate of 4\% into second and third-pillar pensions from 2009 on, starting in a stepwise fashion according to Table 5 . 


\section{Figure 13: Total pension level including private Riester pensions}

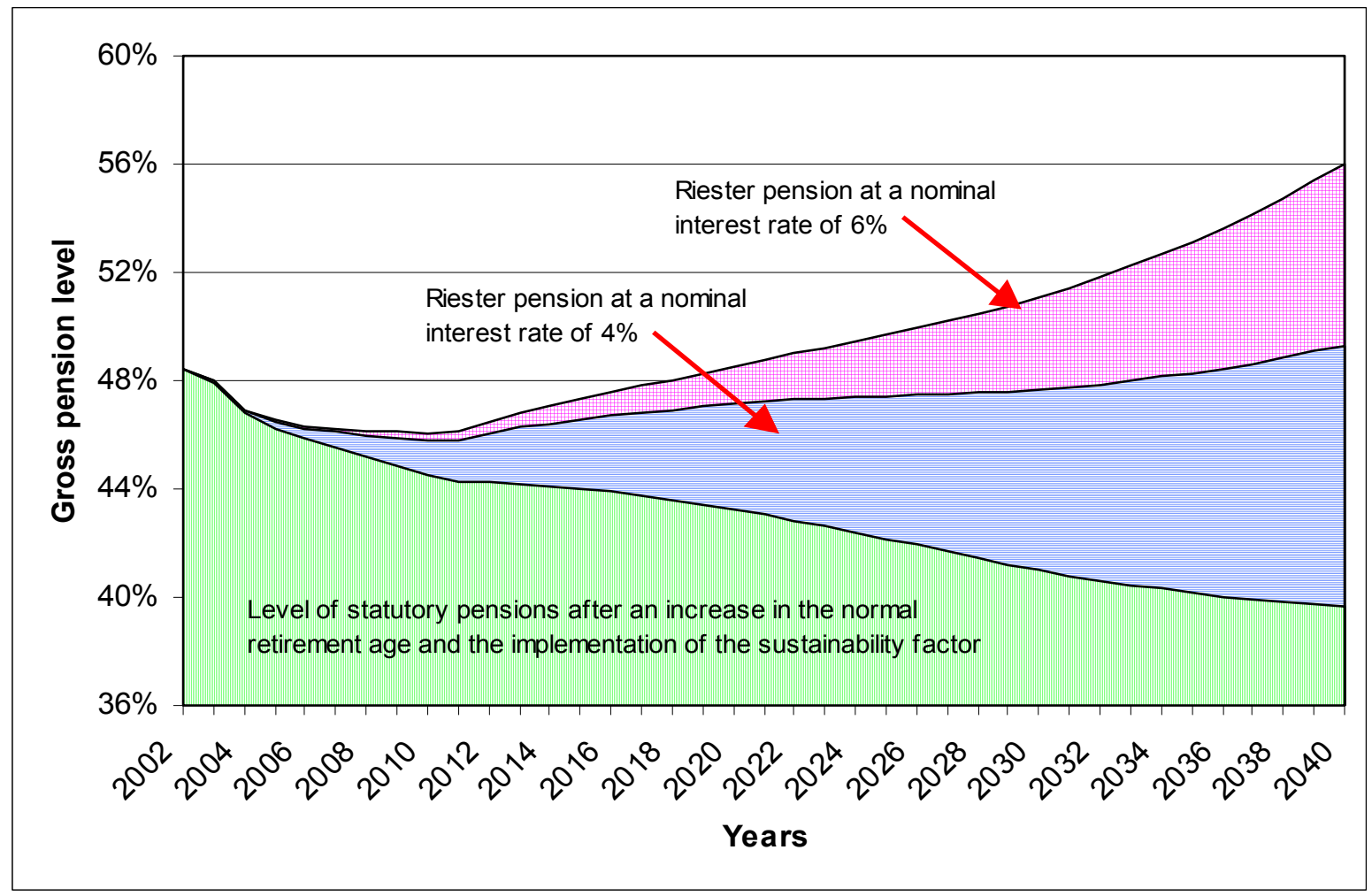

Source: MEA calculations based on the Rürup commission's demographic and labor market projections.

Figure 13 quite clearly shows the crux of all transition models: the transition generation will have to pay extra in order to maintain their total retirement income when the income from payas-you-go pensions is reduced. More refined transition models show that a saving rate of $8 \%$ is sufficient for the cohort with the highest transition burden (Birg and Börsch-Supan, 1999).

\subsection{The 2004 Reform}

Most of the Rürup proposals, and most significantly the introduction of the "sustainability factor", have been passed by the German parliament on March 31, 2004. The shift in the retirement age, however, was not legislated. Since the commission proposed that the phasing-in period should start in 2011, it was decided that there is no need for immediate legislative action. 
The politics of shifting the retirement age are clearly not favorable. According to survey results by Boeri, Börsch-Supan and Tabellini (2001, 2002a and b), raising the retirement age is one of the most unpopular pension reform options in Germany, see Figure 14.

Figure 14: Popularity of pension reform options

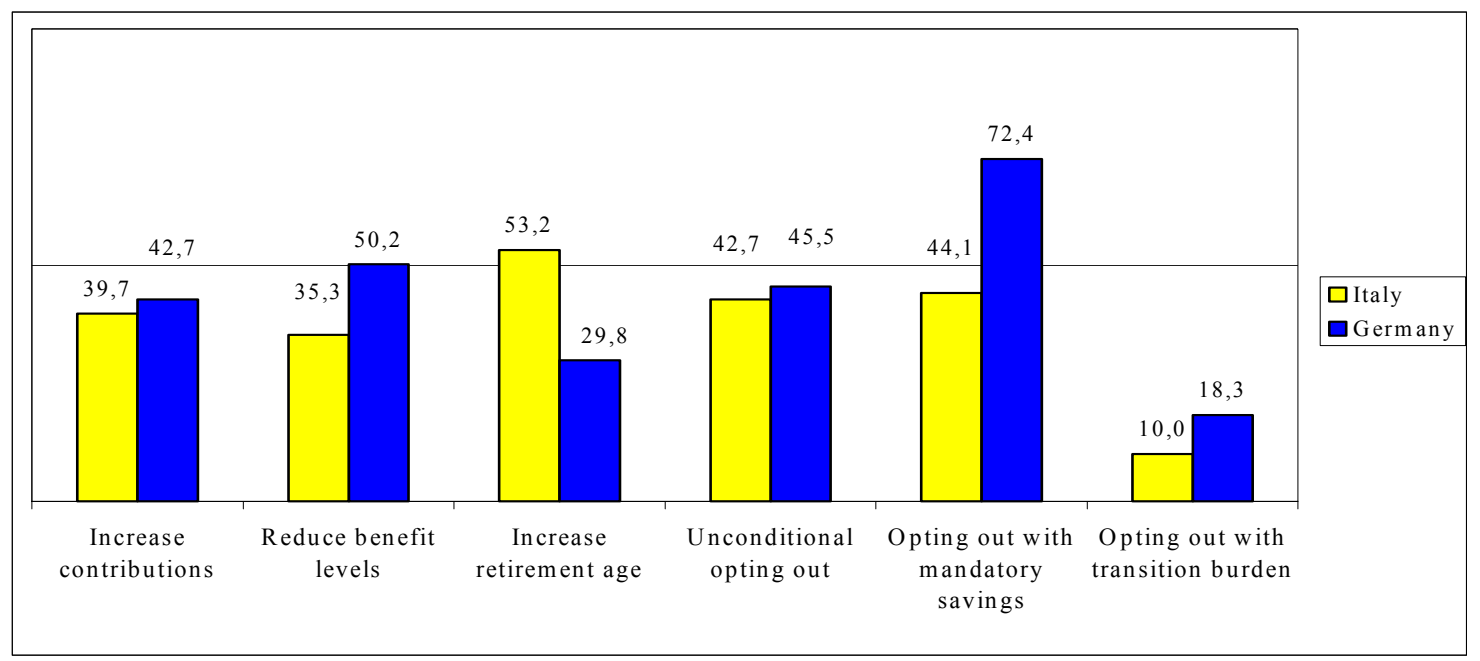

Source: Boeri, Börsch-Supan and Tabellini (2002b)

An interesting result of this survey is that this option is particularly unpopular among those who are least informed about the costs of the current pension system. Hence, while early retirement is a well appreciated social achievement among Germans, awareness of the costs of early retirement may moderate the opposition to increasing the retirement age.

Another lesson from this survey is that the success of a reform depends on the flexibility in the hard choice between a later retirement age and a lower pay-as-you-go pension level, supplemented by private pensions which cut into consumption. As long as pensions are calculated in an actuarially neutral fashion, taking all side effects to the economy into account, there is no need for a "normal retirement age", and workers can decide themselves between working longer and saving more. The recent experience in the US in the aftermath of the bubble burst appears to indicate that workers are quite aware of this substitution. Flexibility minimizes the opposition to reform proposals relative to proposals which make cuts in only one direction, say, increasing the normal retirement age. 
At this point, the German system is not actuarially neutral from the point of workers who decide about their retirement age, see Börsch-Supan and Schnabel (1999). As much as the government shied away from legislating the prospective increase in retirement age, it did not touch the current lack of actuarially neutrality. Both steps have met fierce opposition from unions and pensioner advocacy groups, and, interestingly, the last step also from the employers' union since it increases the costs of severance.

\section{Conclusions}

Part A of this paper described the generous German pension system, as it was in place between 1972 and the end of the nineties. It generated early retirement ages and high replacement rates, but at high costs to society in form of a large cost percentage of GDP (about 12 percent) and high contribution rates (about 28 percent of gross income, of which 19,5 percent are direct contributions and 8,5 percent indirect contributions for state subsidies financed by general taxes).

The Riester reform in 2001, described in Part B, attempts to reduce the tax and contribution burden by transforming the monolithic PAYG system to a multipillar system with subsidized or tax-privileged private pensions in individual accounts or as occupational pensions. The reform is an important first step towards solving the demographic problems confronting the pension system. It does not, however, stabilize the public PAYG pillar in the coming decades.

This instability precipitated the creation of the reform commission chaired by Rürup. In contrast to the Riester reform, this commission took the political risk of proposing a rise in the normal retirement age and a further reduction in long-term benefits at the same time. As a major innovation, this reduction was rationalized by linking benefits to the system dependency ratio. It therefore provides an automatic stabilizer and de facto converts the defined benefit system to a system which mimics a defined contribution system. While this mechanism became law in 2004, the change in retirement age was postponed. Hence, the slow but steady reform process of the German pension system is likely to continue as the German population ages. 


\section{References}

Bäcker, G., R. Bispinck, K. Hofemann, und G. Naegele (2000): „Sozialpolitik und soziale Lage in Deutschland", Westdeutscher Verlag, Wiesbaden.

Bäcker, G., R. Bispinck, K. Hofemann, und G. Naegele (2003): „Sozialpolitik und soziale Lage in Deutschland", www.sozialpolitik-aktuell.de.

Berkel, B., and A. Börsch-Supan (2003): Pension Reform in Germany: The Impact on Retirement Decisions, Finanzarchiv, forthcoming.

Birg, H., and A. Börsch-Supan (1999): Für eine neue Aufgabenteilung zwischen gesetzlicher und privater Altersversorgung, GDV: Berlin.

Boeri, T., A. Börsch-Supan, and G. Tabellini (2001): Would you like to Shrink the Welfare State? The Opinions of European Citizens, Economic Policy, Vol. 32.

Boeri, T., A. Börsch-Supan, and G. Tabellini (2002a): Would you Like to Reform the Pension System? The Opinions of European Citizens, American Economic Review, May 2002.

Boeri, T., A. Börsch-Supan, and G. Tabellini (2002b): How would you Like to Reform your Pension System? The Opinions of German and Italian Citizens, in: R. Brooks and A. Razin (eds.), The Politics and Finance of Social Security Reform, Kluwer, in press.

Bonin, H. (2001): "Will it last? An assessment of the 2001 German pension reform", IZA Discussion Paper (343), Bonn

Börsch-Supan, A. (1998a): "Incentive Effects of Social Security on Labour Force Participation: Evidence in Germany and across Europe," Journal of Public Economics.

Börsch-Supan, A. (1998b): "Zur deutschen Diskussion eines “Übergangs vom Umlage- zum Kapitaldeckungsverfahren in der deutschen Rentenversicherung," Finanzarchiv, 55(3), $400-428$.

Börsch-Supan, A. (1999): “The German Retirement Insurance System,” in: A. Börsch-Supan and M. Miegel (eds.), Pension Reform in Six Countries, Berlin, Heidelberg: Springer, $13-38$.

Börsch-Supan, A. (2000): "Rentenreform und die Bereitschaft zur Eigenvorsorge: Umfrageergebnisse in Deutschland," Beiträge zur angewandten Wirtschaftsforschung (583), Universität Mannheim.

Börsch-Supan, A. (2002): "Eine Blaupause für eine nachhaltige Rentenreform in Deutschland," MEA Discussion Paper (1), Universität Mannheim.

Börsch-Supan, A. and R. Schnabel (1999): Social Security and Retirement in Germany. In: Gruber, J. und Wise, D. A. (eds.), Social Security and Retirement Around the World. Chicago, London: University of Chicago Press, 135-180.

Börsch-Supan, A. (1998): 'Germany: A Social Security System on the Verge of Collapse.' In: H. Siebert (ed.) Redesigning Social Security. Tübingen: J.C.B. Mohr (Paul Siebeck).

Börsch-Supan, A., 2000a, A Model under Siege: A Case Study of the Germany Retirement Insurance System, The Economic Journal, Vol. 110 No. 461, F24-45. 
Börsch-Supan, A., 2000b, Data and Research on Retirement in Germany, National Academy of Sciences, Washington, D.C.

Börsch-Supan, A., 2000c, 'Incentive Effects of Social Security on Labour Force Participation: Evidence in Germany and Across Europe.' Journal of Public Economics, in press.

Börsch-Supan, A., 2001, 'Blaupause für eine nachhaltige Rentenreform.' Mimeo, University of Mannheim.

Börsch-Supan, A., 2002, 'Incentive Effects of Social Security Under an Uncertain Disability Option' in: D.A. Wise (ed.), Frontiers in the Economics of Aging, University of Chicago Press: Chicago.

Börsch-Supan, A., and P. Schmidt, 1996. Early Retirement in East and West Germany, in: R. Riphahn, D. Snower and K. Zimmermann (eds.), Employment Policy in the Transition to Free Enterprise: German Integration and Its Lessons for Europe, London.

Börsch-Supan, A., and R. Schnabel, 1998, Social Security and Declining Labor Force Participation in Germany, American Economic Review 88.2, 173-178.

Börsch-Supan, A., R. Schnabel, S. Kohnz and G. Mastrobuoni, 2004, Micro Modelling of Retirement Choices in Germany, In: J. Gruber and D. Wise (eds.), Social Security Programs and Retirement Around the World: Micro-Estimation, University of Chicago Press, 285-344.

Börsch-Supan, A., und M. Lührmann (2000): "Prinzipien der Renten- und Pensionsbesteuerung," Frankfurter Institut - Stiftung Marktwirtschaft und Politik, Bad Homburg.

Börsch-Supan, A., und R. Schnabel (1999): "Social Security and Retirement in Germany," in: J. Gruber, und D. Wise (eds.), Social Security Programs and Retirement Around the World, The University of Chicago Press, Chicago.

Breyer, F. (1989): "On the Intergenerational Pareto-effciency of Pay-As-You-Go Financed Pension Systems," Journal of Institutional and Theoretical Economics, (145), 643-658.

Brunner, J. (1994): "Redistribution and the Effciency of the Pay-as-you-go Pension System," Journal of Institutional and Theoretical Economics, (150), 511-523.

Bundesministerium für Arbeit und Sozialordnung, (BMA), 1997, Statistisches Taschenbuch, Bonn: Bundespresseamt.

Burger, A. (1998): „Reform der Rentenversicherung: Chancen und Risiken des Kapitaldeckungsverfahrens“, Deutsche Rentenversicherung, S.655-672.

Burkhauser, R., 1991, An Introduction to the German Socio-Economic Panel For English Speaking Researchers, mimeo, Syracuse University

Buslei, H., und F. Kraus (1996): "Wohlfahrtseffekte eines graduellen "Übergangs auf ein niedrigeres Rentenniveau," in: Soziale Sicherung und Arbeitsmarkt: Empirische Analyse und Reformansätze, hrsg. v. V. Steiner, und K. Zimmermann, S. 57-92. BadenBaden.

Casmir, B., 1989. Staatliche Rentenversicherungssysteme im internationalen Vergleich, Lang, Frankfurt. 
Coile, Courtney, 1999, “Retirement Incentives and Couples' Retirement Decisions," Ph.D. Dissertation, MIT.

Coile, Courtney, and Jonathan Gruber, 1999, "Social Security and Retirement," mimeo, MIT.

Cutler, D., and L.M. Sheiner, 1998, 'Demographics and Medical Care Spending: Standard and Non-Standard Effects.' Mimeo, Harvard University.

Deutsche Bundesbank (2002): "Kapitalgedeckte Altersvorsorge und Finanzmärkte," Monatsbericht Juli, Frankfurt am Main.

Eitenmüller, S. und W. Hain (1998): „Potenzielle Effizienzvorteile kontra Übergangskosten: Modellrechnungen $\mathrm{zu}$ den Belastungswirkungen bei einem Wechsel des Finanzierungsverfahrens in der gesetzlichen Rentenversicherung“, Deutsche Rentenversicherung, 634-654.

Fenge, R. (1995): "Pareto-Effciency of the Pay-As-You-Go Pension System with intergenerational Fairness," Finanzarchiv, (52), 357-363.

Gruber, J., and D.A. Wise (eds), 1999, Social Security and Retirement Around the World. University of Chicago Press: Chicago.

Gruber, J., and D.A. Wise (eds.), 2002, Incentive Effects of Public Pension Systems, University of Chicago Press, in press.

Himmelreicher, R.K. und H. Viebrok (2002): „Die Riester-Rente und einige Folgen für die Alterseinkünfte“, ZeS Arbeitspapier, Bremen

Jacobs, K., Kohli, M. and Rein, K., 1990, Germany: the Diversity of Pathways, in: M. Kohli, M. Rein, A.-M. Guillemard, and H. van Gunsteren (eds.), Time for Retirement: Comparative Studies of Early Exit from the Labor Force, Cambridge University Press, Cambridge, New York.

Karl Bräuer Institut des Bundes der Steuerzahler (2001): "Zu den Rentenreformplänen der Bundesregierung," Sonderinformation 40, Wiesbaden.

Kommission für die Nachhaltigkeit in der Finanzierung der Sozialen Sicherungssysteme (2003): Abschlußbericht. Bundesministerium für Gesundheit und Soziale Sicherheit, Berlin. (http://www.bmgs.bund.de/deu/gra/themen/sicherheit/kommission/index.cfm).

Leinert, J. (2003): „Die Riester-Rente: Wer hat sie, wer will sie: Vorausbewertung einer repräsentativen Umfrage zum Vorsorgeverhalten der 30- bis 50-Jährigen“, Bertelsmann Stiftung Vorsorgestudien 14, Gütersloh

OECD, 2001, Ageing and Income: Financial Resources and Retirement in 9 OECD Countries, Organisation for Economic Co-Operation and Development, Paris.

Prognos, 1987, "Gesamtwirtschaftliche Entwicklungen und Gesetzliche Rentenversicherung vor dem Hintergrund einer schrumpfenden Bevölkerung", Prognos AG, Basel.

Prognos, 2001, „Reformoptionen für die gesetzliche Rentenversicherung: Auswirkungen der Rentenreform 2001 und die Verteilung der Umstiegskosten", Prognos AG, Basel

Raffelhüschen, B. (1993): "Funding Social Security Through Pareto-Optimal Conversion Policies," Journal of Economics, S. 105-131. 
Rehfeld, U. (2000): „Die Bedeutung der gesetzlichen Rentenversicherung im Drei-SäulenModell - Ergebnisse aus der Sondererhebung AVID“, VDR - Pressekontaktseminar 2000, Dresden

Riphahn, Regina T., 1995, Disability Retirement Among German Men in the 1980s, Münchner Wirtschaftswissenschaftliche Beiträge, Nr. 95-20, Ludwig Maximilians Universität München.

Ruppert, W. (2000): „Betriebliche Altersversorgung“, Institut für Wirtschaftsforschung (ifo), München.

Schmähl, W., 1991, Alterssicherung in der DDR und ihre Umgestaltung im Zuge des deutschen Einigungsprozesses - Einige verteilungspolitische Aspekte, in: G. Kleinhenz (ed.) Sozialpolitik im vereinten Deutschland, Duncker \& Humblot, Berlin.

Schmidt, P. (1995): „Die Wahl des Rentenalters: Theoretische und empirische Analyse des Rentenzugangsverhältnis in West-und Ostdeutschland“, Lang, Frankfurt.

Schnabel, R., 1999, Opting Out of Social Security: Incentives and Participation in the German Public Pension System, SFB504-Discussion Paper No. 99-42, University of Mannheim.

Schnabel, Reinhold, 1998, Rates of Return of the German Pay-As-You-Go Pension System, Finanzarchiv, 55(3), 374-399.

Siddiqui, S. (1997): "The pension incentive to retire: empirical evidence for West Germany," Journal of Population Economics, 10(4), 463-486.

Stiftung Warentest (2002): „Riester-Rentenversicherungen: Die Lücke schließen“, FINANZtest $9 / 2002$

Stock, J.H., and Wise, D.A., 1990, The Pension Inducement to Retire: An Option Value Analysis, in: D.A. Wise (ed.) Issues in the Economics of Aging, Chicago: University of Chicago Press, 1990, 205-30.

Summers, L, Some Simple Economics of Mandated Benefits, American Economic Review, Vol. 79, No. 2, May 1989.

Verband deutscher Rentenversicherungsträger (VDR), 1997, 2002, Die Rentenversicherung in Zeitreihen, Frankfurt am Main. 